\title{
Doğuşu ve Tarihsel Gelişimi Bağlamında İslam Hukukunda İhtilaf
}

\author{
Yüksel Salman \\ Dr. Öğr. Üyesi, Ankara Yıldırım Beyazıt Üniversitesi (ROR ID: 05ryemn72) \\ İslami İlimler Fakültesi, İslam Hukuku Anabilim Dalı \\ Assistant Professor Dr., University of Ankara Ylldrrm Beyazit, Faculty of Islamic Studies Department of Islamic Law \\ Ankara/Turkey \\ ysalman67@hotmail.com \\ ORCID: 0000-0001-5747-9639
}

\section{Ikhtilaf in Islamic Law in the Context of its Emergence and Historical Development Abstract}

Ikhtilaf (differences of opinion on religious matters) is a natural phenomenon. Throughout the history, different views and understandings have always existed. This fact should be taken into account while evaluating the ikhtilaf on figh (jurisprudence) matters. The ikhtilaf that are in contradiction with the nass, the ijma, and the general tenets and principles of Islam have not been approved throughout the history of Islamic law. The duly-conducted ijtihad made by the qualified fuqaha (figh scholars) on matters open to ijtihad, and the ikhtilaf that occurring as their consequence are, however, evaluated as a reason for mercy. The scholars of Islamic law in the period of the Companions and the subsequent periods have had disagreements on many issues. However, this situation was not seen as a reason for dissension (fitnah) except for some marginal views. While the differences of opinion were met with more understanding and accepted as richness in thought, they began to be criticized and their legitimacy to be questioned after the second Hijri century. General rulings of some verses that prohibit ikhtilaf were shown as the basis for this approach.

Differences of opinion while the Prophet was still alive were resolved by the Messenger of Allah himself. Therefore, it is not possible to mention about an ikhtilaf in the real sense in that period. But since the revelation stopped and no source of resolution left with his demise, we can say that the first serious differences of opinion arose. The main reasons for ikhtilaf in the period of the Companions can be counted as not reaching the related nass or ruling, the fact that the hadith has not come through an.

The differences of opinion that arose in the period of tabi'un (successors of companions) were mostly based on place and region. Main reasons for the ikhtilaf in that period are the use of words literally or metaphorically, the hadith's being known or not, the authenticity of the hadith, difference of knowledge and method of ijtihad, and social circle. The new cultures and understandings emerged with the conquests, the effects of ra'y and hadith schools, and differences of opinion resulting from evidence, language, and geography are among other reasons for the ikhtilaf in tabi'un period.

Intihal Taraması/Plagiarism Detection: Bu makale intihal taramasından geçirildi/This paper was checked for plagiarism Geliş/Received: 31 Mayıs/May 2020|Kabul/Accepted:02 Eylül/September 2020|Yayın/Published: 20 Eylül/September 2020 Atff/Cite as: Yüksel Salman, "Doğuşu ve Tarihsel Gelişimi Bağlamında İslam Hukukunda İhtilaf = Ikhtilaf in Islamic Law in the Context of its Emergence and Historical Development”, Eskiyeni 42 (Eylül/September 2020), 927-960.

https://doi.org/ 10.37697/eskiyeni.745925

Copyright $\odot$ Anadolu İlahiyat Akademisi/Anatolian Theological Academy, 06050, Ankara, Turkey |www.anilakademi.com CC BY-NC 4.0 | This paper is licensed under a Creative Commons Attribution-NonCommercial License 
Borders of the Islamic state reached Spain and China, and social and cultural dynamism increased in the period of mujtahid imams, from the beginning of the $2^{\text {nd }}$ century to the $4^{\text {th }}$ century after Hijrah. Comprehensive interpretations of the Qur'an and the Sunnah, and the rich accumulation consisting of the ijtihad of Companions and fuqaha tabi'un have formed massive data for the systematization of Islamic fiqh. While the schooling was around basic trends in the period of tabi'un, in this period, a person-centered new legal structure called "madhhab" (Islamic jurisprudence school) emerged among these schools.

The phenomenon of imitation left its mark on the "madhhab and literature-centered development period" starting with the second half of the $4^{\text {th }}$ century after Hijrah and continuing until the conquest of Baghdad by the Mongols. Absolute ijtihad (ijtihad al-mutlaq) gradually decreased in this period while strict adherence to a certain madhhab and previous ijtihads came to the fore. This period is also the one when Islamic jurisprudence matured in the context of concept, theory and method, and settled as a tradition. For this reason, this period is also called "the period of stability" or "the period of institutionalization" by some. As the absolute ijtihad era ended in this period, followers of each madhhab adhered to their imam. Islamic law continues to have an effect on organizing life in Muslim societies, whose number is today close to two billion worldwide. In today's world where multidimensional developments are experienced in every field of social life and thus legal problems are increasing and deepening, some of the studies in Islamic law continue at legislation level while others are held at the academic level in the official and civil field, particularly in universities.

We can say that in addition to many boards and organizations that focus on fatwa, scientific studies conducted in universities also shed light on the solution of today's jurisprudential problems, help to eliminate the legally-baseless ikhtilaf, and contribute to the development of common-sense approaches.

In this study, by which we tried to reveal the emergence and historical development of ikhtilaf in the Islamic law, the political factors affecting the course of ikhtilaf, the environmental factors, the elements regarding time and geography, and the differences of methods adopted by Islamic jurists are discussed. Contemporary studies on Islamic law are also included in addition to the classical sources of fiqh. This study aims to position the fact of ikhtilaf correctly and to draw attention to its legal nature. Understanding the ikhtilaf and its historical course will open the door to comprehending the reasons behind different opinions in Islamic law and to richness in views. It will also make significant contributions to prevention of ikhtilaf-based separations.

It is a fact that it is impossible to imagine a world without ikhtilaf. Although it is a wellintended thought to expect all mujtahids to have the same opinion or everyone to obey an opinion in subjects open to ijtihad, we need to state that it does not have religious, legal or rational basis. What really matters is to accept the fact of ikhtilaf, comprehend its legal nature, and evaluate it as a different horizon.

\section{Keywords}

Islamic Law, Ikthilaf, Khilaf, Ikthilaf on Fiqh, Different Opinion, Secession

\section{Doğuşu ve Tarihsel Gelişimi Bağlamında İslam Hukukunda İhtilaf}

\section{Öz}

İhtilaf tabii, fitrî bir olgudur. İnsanın olduğu yerde tarih boyunca farklı görüş ve anlayışlar hep var olmuştur. Fıkhî ihtilafları değerlendirirken de bu gerçekliği dikkate almak gerekir. İslam hukuk tarihi boyunca naslara ve icmâya aykırı olan, İslam'ın genel ilke ve prensipleriyle ters düşen ihtilaflar tasvip edilmemiştir. İçtihada açık olan konularda liyakat sahibi fakihlerce 
usulüne uygun şekilde yapılan içtihatlar ve bunun sonucu ortaya çıan ihtilaflar ise bir rahmet sebebi olarak değerlendirilmiștir. Sahâbe ve sonraki dönemlerde İslam hukukçuları birçok meselede ihtilaf etmişlerdir. Bu durum, bazı marjinal görüşler dışında, bir fitne sebebi olarak görülmemiştir.

İlk dönemlerde daha anlayışla karşılanan ve düşüncede zenginlik kabul edilen ihtilaflar, hicrî 2. asırdan sonra eleştirilmeye ve meşrûiyeti sorgulanmaya başlamıştır. İhtilafı yasaklayan bazı âyetlerin genel hükümleri de buna dayanak olarak gösterilmiştir.

Hz. Peygamberin sağlığında iken sahâbe arasında yaşanan bazı ihtilaflar, Allah'ın elçisi tarafindan çözüme kavuşturulmuştur. Bu dönemde gerçek anlamıla bir ihtilaftan söz edilemez. Hz. Peygamberin vefatıyla birlikte vahiy kesildiği ve ihtilafların çözüm mercii kalmadığından, ciddi anlamda ilk ihtilafların baş gösterdiğini söyleyebiliriz. İlgili nas veya hükme ulaşmamış olmak, hadisin sağlam bir kaynaktan ulaşmamış olması, farklı anlayışlar, farklı yorumlamalar, unutma ve yanılmalar, sahabe döneminin başlıca ihtilaf sebepleri olarak zikredilebilir.

Tabiîn dönemde ortaya çıkan ihtilaflar daha çok mekân ve bölgeye dayalı ithilâflardır. Sözün hakikat veya mecazî anlamda kullanılması, hadisin bilinip bilinmemesi, hadisin sıhhati, içtihat bilgi ve usûlünün farklılığı ve sosyal çevre başlıca ihtilaf sebepleri arasındadır. Fetihlerle birlikte ortaya çıkan yeni kültür ve anlayışlar, re'y ve hadis ekollerinin etkisi, delile, dil ve coğrafyaya bağlı ihtilaflar da tâbiînin döneminde yaşanan ihtilafların sebepleri arasındadır.

Hicrî ikinci yüzyılın başlangıcından dördüncü yüzyılın ortalarına kadar devam eden müçtehit imamlar döneminde, İslam ülkesinin sınırları İspanya ve Çin'e kadar ulaşmış, sosyal ve kültürel hareketlilik artmıştır. Kur'an ve Sünnete ilişkin kapsamlı yorumlar, sahâbe ve tâbiîn fakihlerinin içtihatlarından oluşan zengin birikim, İslam fikhının sistemleştirilmesinde güçlü bir veri oluşturmuştur. Tâbiîn döneminde temel eğilimler etrafında bir ekolleşme yaşanırken, bu dönemde söz konusu ekoller içinden "mezhep" adıyla şahıs merkezli yeni bir hukukî yapılanma ortaya çıkmıştır.

Hicrî dördüncü asrın ikinci yarısından Bağdat'ın Moğollar tarafından ele geçirilmesine kadar devam eden süreyi kapsayan "mezhep ve literatür merkezli gelişme dönemi"ne taklit olgusu damgasını vurmuştur. Bu dönemde mutlak içtihat faaliyetleri giderek azalmış, belli bir mezhebe ve önceki içtihatlara sıkı sıkıya bağlı kalma ön plana çıkmıștır. Bu dönem, aynı zamanda fikhın kavram, teori ve usûl bağlamında olgunlaştığı ve gelenek halinde kökleştiği bir dönemdir. Bu yüzden "istikrar dönemi” veya "kurumsallaşma dönemi” diyenler de vardır. Bu dönemde mutlak içtihat devri sona erdiğinden, her mezhebin mensupları kendi imamlarına bağlanmıștır.

İslam hukuku, günümüzde dünya genelinde sayıları iki milyara yaklaşan Müslüman toplumlarda hayatı düzenlemedeki etkisini sürdürmektedir. Sosyal hayatın her alanında çok yönlü gelişmelerin yaşandığı, buna bağlı olarak hukukî problemlerin arttığı ve derinleștiği günümüzde, İslam hukuku alanında yapılan çalışmaların bir kısmı kanunlaştırma düzeyinde bir kısmı da başta üniversiteler olmak üzere resmî ve sivil alanda akademik düzeyde sürmektedir. Fetva merkezli çalışan birçok kurul ve oluşumların yanı sıra, üniversiteler bünyesinde yapılan bilimsel çalışmaların da günümüz fikıh problemlerinin çözümüne ışık tuttuğu, hukukî temelden yoksun ihtilafların ortadan kaldırılmasına yardımcı olduğu ve sağduyulu yaklaşımların gelişmesine katkı sağladığını söyleyebiliriz.

İslam hukukunda ihtilafın doğuşu ve tarihsel süreçteki gelişimini ortaya koymaya çalıştığımız bu çalışmada, ihtilafın tarihsel süreçteki seyrini etkileyen siyasî etkenler, çevre faktörü, zaman ve coğrafyaya bağlı unsurlar ile İslam hukukçularının benimsediği yönteme dayalı farklılıklara temas edilmiştir. Çalışmada klasik fikıh kaynaklarının yanı sıra, bu alanda yapılan 
çağdaş İslam hukuku çalışmalarına da ağırlıklı olarak yer verilmiştir. Çalışmanın amacı, ihtilaf gerçeğini doğru konumlandırmak, ihtilafın hukukî niteliğine dikkat çekmektir. İhtilafı ve tarihsel süreçteki seyrini doğru anlamak, İslam hukukundaki farklı görüşlerin gerekçelerini kavramaya ve fikirde zenginliğe kapı aralayacaktır. İhtilaf temelli ayrışmaları önlemede de önemli katkılar sağlayacaktır.

Şu bir gerçek ki ihtilafsız bir dünya tasavvur etmek imkânsızdır. İçtihada açık konularda bütün müçtehitlerin aynı kanaate sahip olmasını veya bir görüşe herkesin tabi olmasını beklemek, ihtilafı ortadan kaldırmak gibi temelde iyi niyete dayalı bir düşünce olsa da bunun dinî, hukukî ve rasyonel zemini olmadığını ifade etmeliyiz. Aslolan ihtilaf gerçeğini kabul etmek, hukukî niteliğini kavramak ve farklı bir ufuk olarak değerlendirebilmektir.

\section{Anahtar Kelimeler}

İslam Hukuku, İhtilaf, Hilâf, Fıkhî İhtilaf, Farklı Görüş, İftirak

\section{Giriş}

Her insan ayrı bir değer ve farklı bir dünyadır. İnsanların fikirleri, eğilimleri, hadiseler karşısındaki tutum ve davranışları aynı değildir. Kavrayış ve zekâ düzeyi, mesleki bilgi ve beceri, teknik, sanat, edebiyat ve ilme yatkınlık kişiden kişiye göre değişkenlik arz eder. İnsanın doğuştan sahip olduğu ve zamanla geliştirdiği kişisel özellikleri fitratın bir yansıması ve doğal ihtilaf sebebidir.

İnsanları birbirine yaklaştıran, paylaşma ve dayanışmayı artıran bu farklılıklar hayatın bir gerçeğidir. Her meslekten insana ihtiyaç duyulan bir dünyada, farklı kabiliyetler insanlık ailesi için birer zenginlik, kolaylık ve genişlik sebebidir. Hayatın devamı için de toplumsal bir zarurettir. Kur'an-1 Kerim'de, Allah'ın insanları yeryüzünde halifeler kıldığına ve verdiği nimetler konusunda imtihan etmek için bazılarını üstün kıldığına değinilmesi dikkat çekicidir. ${ }^{1}$ Yine “...Dünya hayatında onların geçimlerini aralarında biz paylaştırdık. Birbirlerine iş gördürmeleri için (çeşitli alanlarda) kimini kimine, derece derece üstün kıldık..." âyetiyle kişisel farklılıkların kolektif çalışma vesilesi ve hayatın devamı için de gerekli olduğuna vurgu yapılması anlamlıdır.

Her biri değerli bir bütünün parçası ve Sünnetullah'ın bir yansıması kabul edebileceğimiz bu farklılıklar "tabii ihtilaf" olarak değerlendirilmiştir. Bireyler, topluluklar, bilimsel ve felsefî oluşumlar arasında ortaya çıkan ve gelişen farklılıklar ise "kesbî ihtilaf" olarak nitelendirilmiştir. Bu bağlamdaki bir ihtilafta her görüş sahibi kendi fikrinin doğru, karşı tarafın ise hatalı olduğunu kabul etmektedir. ${ }^{4}$ Fıkhî ihtilafları da bu kapsamda değerlendirmek mümkündür. ${ }^{5}$ Şunu da belirtelim ki görüş ayrılığı, taraflar arasında asgari müştereklerin varlığının bir göstergesidir. ${ }^{6}$

\footnotetext{
Kur'an Yolu Meâli, haz. Hayreddin Karaman vd. (Ankara: Diyanet İşleri Başkanlı̆̆ı Yayınları, 2017), elEn'âm 6/165.

2 ez-Zuhruf $43 / 32$.

3 Şükrü Özen, “İhtilaf”, Türkiye Diyanet Vakfi İslâm Ansiklopedisi (Ankara: TDV Yayınları, 2004), 21/565.

4 Ebu'l-Kâsım Hüseyin b. Muhammed Râgıb Isfahânî, el-Müfredât fi garîbi'l-Kur'ân (Mekke: Mektebetü Nezzâr Mustafa el-Bâz, 2009), 1/207.

5 Ali b. Muhammed b. es-Seyyid Şerîf Cürcânî, et-Ta'rîfât (b.y.: y.y., ts.), 101.

6 Özen, “İhtilaf”, 21/565.
} 
Bu çalışmada ihtilaf, doğuşu, tarihsel süreçteki dönemsel özellikleri ve İslam hukukuna yansıyan yönleriyle ele alınacaktır. Her dönemin kendine özgü ilmî, siyasî yapısı, sosyal ve çevresel şartları ve bunların İslam hukukuna yansımaları bulunduğundan, kronolojik bir okuma yapılmaya çalışılacaktır. Kuşkusuz sebep ve sonuçlarıyla bütün fıkhî ihtilafları ortaya koymak, bu çalışmanın boyutlarını aşacak kadar geniştir. Bu itibarla ihtilaflar, öne çıkan yönleriyle ele alınacak ve yeri geldiğince ihtilaf örneklerine yer verilecektir.

İslam hukuk tarihinde önemli bir yer tutan "ihtilaf”' doğru anlamak, hukuk ekolleri arasındaki farklılıkların gerekçelerini yakından tanımaya, düşüncede zenginliğe ve görüşlere saygı göstermeye kapı aralayacaktır. İhtilafa dayalı ayrışmaları önlemede, hasmâne tutum ve davranışları azaltmada da etkili olacağını söyleyebiliriz.

\section{1. İhtilaf ve Hilâf}

Geride kalmak, anlaşmazlık, görüş ayrılığı, çekişmek, farklı görüşü benimsemek, karşı gelmek gibi anlamlara gelen "h-l-f" kelimesinden türeyen ihtilaf, bir kavram olarak söz veya davranışta birinin tuttuğu yolun dışında bir yolu benimsemektir. ${ }^{8}$

Bir konuda birliğin oluşmaması, söz veya davranışta iki taraftan birinin diğerini ilzam etmesi, bir hususta görüşlerin ve yöntemin birbirinden farklı olması anlamlarına da gelmektedir. ${ }^{9}$ İhtilafın delile dayandığı, aynı kökten gelen hilâf kavramının ise böyle olmadığı ifade edilmekle birlikte, hilâf ve ihtilaf kavramlarını aynı anlamda kullanan âlimler de vardır. ${ }^{10}$

İhtilaf, bir konuda yol/yöntem ayrı olsa da amacın bir olması, hilâf ise hem yolun/yöntemin hem de gayenin farklı olması anlamında da kullanılmıştır. ${ }^{11}$ İhtilaf, görüşler arasında güçlü ve zayıf ayrımı yapmayıp tarafsız kalma anlamı taşıması sebebiyle, olumlu bir çağrışıma sahiptir. Hilâf ise bir görüşü benimseme, savunma ve karşı görüşlere tavır alışı ifade etmektedir. ${ }^{12}$ Denilebilir ki hilâf, işin özü ve aslıyla, ihtilaf ise, şekil ve lafızdaki farklılık ile yakından ilgilidir.

\section{2. İslam Hukukunun Karakteristik Yapisı ve İhtilaf}

Naslar sınırlı, insanların karşılaştıkları meseleler ise sınırsızdır. Kur'an ve

\footnotetext{
İbrahim Üneys vd., el-Mu'cemü'l-vesit (ìstanbul: el-Mektebetü'l-i̇slâmiyye, ts.), 1/251.

8 Ebu'l-Fadl Cemâlüddîn Muhammed b. Mükrim İbn Manzûr, Lisânül'-Arab (Kahire: Dâru'l-Fikr,1990), 9/9091.

9 Muhammed Avvâme, Edebü'l ihtilâffímesâili'l-ilmi ve'ddîn (Beyrut: Dâru'l-Beşâir el-İslâmiyye, 1997), 8.

10 Mahmud Abdullatîf Mahmud, el-îhtilâfâtul-fikhiyye ledel-itticâhâti'l-islâmiyye el-muâstra (Mansûra: Dâru'lVefâ, 2008), 14; Ahmed b. Muhammed el-Ensârî, Âsâru ihtilâfil-fukahâ fi's-şerîa (Riyad: Mektebetü Rüşd, 1996), 8.

11 Avvâme, Edebü'l-ihtilâf, 8-9.

12 Halis Demir, "Hanefi Mezhebinde Hilâf Literatürü", Cumhuriyet Üniversitesi İlahiyat Fakültesi Dergisi 19/2 (Aralık 2015),114.
} 
Sünnet, çoğu zaman evrensel hükümler ve ilkeler koymuştur. Evlenilmesi yasak olan kişiler, evliliğin sona ermesi akabinde kadınların iddeti, miras hisseleri ve had cezaları gibi sınırlı sayılabilecek hükümler dışında ayrıntılara girilmemiş, genel olarak evrensel nitelikte ilke ve hükümler konulmuştur. Bu ilkelerin farklı özelliklere sahip zaman ve coğrafyalarda nasıl uygulanacağı, başka bir ifadeyle evrensel olan nasların sürekli değişebilen pratik olaylara uygulanmasıyla naslardaki sürekliliğin nasıl sağlanacağı meselesi tarih boyunca güncelliğini korumuştur. Nasları anlama, yorumlama ve fikhî meselelerin çözümüne ilişkin geliştirilen yöntem ve yaklaşım biçimini ifade eden mezhepler, bu konuda oluşan düşünce sisteminin bir yansımasıdır.

İslam hukuk tarihi boyunca Kitap ve sünnetin açıcça hükmünü ortaya koyduğu ve ümmetin üzerinde ittifak ettiği konularda ihtilaf doğru karşılanmazken, sübût ve delalet yönüyle kesinliğin bulunmadığı hallerde ihtilaf genel olarak olağan karşılanmıştır. ${ }^{13}$ illkesel olarak -hata ihtimaliyle birlikte- kendi mezhep görüşünü doğru kabul eden, diğer mezhepleri de -doğru olma ihtimalini göz ardı etmeden- hatalı kabul eden anlayışın, genel olarak kabul gördüğünü söyleyebiliriz. ${ }^{14}$

İlk dönemlerde daha anlayışla karşılanan ve düşüncede zenginlik kabul edilen ihtilaflar, hicrî 2. asırdan sonra eleştirilmeye ve meşrûiyeti sorgulanmaya başlamıştır. İhtilafı yasaklayan bazı âyetlerin genel hükümleri de buna dayanak gösterilmiştir. ${ }^{15} \mathrm{Bu}$ görüşü benimseyenler, dinde asıl olanın ihtilaf değil ittifak olduğunu dile getirmişlerdir. Ancak bu görüşte olanların önemli bir kısmına göre dinde hoş karş1lanmayan ihtilaf, içtihat sonrasında farklı görüşlerin benimsenmesi olmayıp, deliller ortaya koyulduktan sonra ihtilafın sürdürülmesidir. İbn Hazm'ın dinde ihtilafın caiz olmayışını, hakkında nas bulunan ve âlimlerin icmâ ettiği konularla ilişkilendirmesi de bu yöndeki kanaati destekler niteliktedir. ${ }^{16}$

\section{Hz. Peygamber Dönemi ve İhtilaf}

Vahiy sürecinin devam ettiği ve tebliğ faaliyetinin sürdüğü döneme İslam hukuk tarihinde "teşrî dönemi" adı verilmektedir. Teşrî sürecinde vahiy, bazen doğrudan bazen sorulan bir soru üzerine bazen de gelişen bir olay sebebiyle tedriç metodu ve kolaylık prensibi gözetilerek yaklaşık 23 yıllık (kamerî) bir süreçte tamamlanmıştır. ${ }^{17}$ Hz. Peygamber, inen âyetleri insanlara tebliğ etmiş, vahyin içeriğini beyan etmiş ve ihtilaflı konularda hüküm vermiştir. ${ }^{18}$ Allah resulünün dinî konulardaki emir ve yasakları sahâbe tarafından tereddütsüz uygulanmıştır. O nasıl abdest alıyor ve namaz kılı-

\footnotetext{
${ }^{13}$ Hayreddin Karaman, İslâmın Işı̆̆ında Günün Meseleleri (İstanbul: İz Yayıncllık, 2001), 3/409.

14 Muhammed Emîn İbn Âbidîn, Reddü'l-muhtâr ale'd-dürri'l-muhtâr şerhu tenvîri'l-ebsâr (b.y.: Matba-i Âmire, 1272), 1/33. Ayrıca ayrıntılı bilgi için bk. Mehmed Fıkhî el-Aynî. Risâle fi edebil-müftî, thk. Osman Şahin (İstanbul: TDV İslam Araştırma Merkezi,1439/2018), 109.

15 Âl-i İmrân 3/19; en-Nisâ 4/82; eş-Şûrâ 42/13.

16 Ali b. Ahmed b. Saîd İbn Hazm, el-ìhkâm fi usûli'l-ahkâm (Beyrut: Dârü'l-Kütübi'l-ìlmiyye, ts.), 5/70.

17 Abdülvehhâb Hallâf, Hulâsatu't-teşrîil-íslâmî. (Kahire: Matba'atu'n-Nasr,1956), 284.

18 Abdülkerîm Zeydan, el-Medhal li dirâseti'ş-şerîati'l-íslâmiyye.(Beyrut: Mektebetü'l-Kuds, 1986), 116.
} 
yorsa, sahâbe aynen tatbik etmiştir. Hz. Peygamber, çoğu zaman bir ibadetin yahut iş ve işlemin olmazsa olmazlarına yahut bunlar eksik olduğunda ibadetin/eylemin geçersiz olacağına ilişkin bir açıklama getirmemiştir. Sahâbe de olayların tabii akışı içerisinde öğrendiklerini tatbik etmiştir. Hâdisenin arka planı veya nedenlerine yönelik Hz. Peygambere her seferinde bir sual yöneltilmemiştir. Tebliğ süreci boyunca gelişen hadiselerle ilgili Hz. Peygamberin ve ashabının genel tavrının böyle cereyan ettiğini söyleyebiliriz. ${ }^{19}$

Teşrî sürecinde hüküm kaynağı Kitap ve Sünnet'tir. Bu iki kaynakla sabit olan sarîh hükümlerde ihtilaf söz konusu değildir. Bedir esirlerine yapılacak muamele ve Tebük savaşına gitmemek için izin isteyen kişilere izin vermesinde olduğu gibi vahiy hükmü bulunmayan konularda Hz. Peygamber içtihadıyla karar vermiştir. Ashabın içtihadına da izin vermiştir. ${ }^{20}$ Muâz b. Cebel'i Yemen'e vali olarak tayin ettiğinde, ona Kitap ve Sünnet'te bir meselenin hükmünü bulamadığında ne yapacağını sorması üzerine: "re'yimle karar veririm ve konuyu cevapsız bırakmam." şeklinde cevap vermesinden memnun olmuş ve Allah'a hamd etmiştir. ${ }^{21}$

Hz. Peygamberin sağlığında iken sahâbe arasında yaşanan bazı ihtilaflar, Hz. Peygambere arz edildiği ve verdiği karar çerçevesinde hareket edildiği için bunlar da sünnet kapsamında değerlendirilmiştir. ${ }^{22}$ Ebû Saîd el-Hudrî’nin rivayetine göre, seferde iken namaz kılmak isteyen iki sahabî su bulamayınca teyemmüm ederek namazlarını kılmışlardır. Vakit çıkmadan su bulmaları üzerine biri abdest alarak namazını iade etmiş, diğeri etmemiştir. Hz. Peygambere durumu haber verdiklerinde, namazını iade etmeyen kişiye; "Sünnete uygun davrandın, namazın senin için yeterlidir" buyurmuşlardır. Diğer kişiye de "Sana iki kat mükafat var" diyerek her ikisinin yaptığını da onaylamıştır. ${ }^{23}$ İslam hukukçuları bu hadiseden hareketle içtihada dayalı meselelerde ihtilafın meşrû olduğuna ve içtihat sonucu ulaşılan görüşlerden her birinin değerli addedileceği kanaatine varmışlardır. ${ }^{24}$ Müçtehidin isabet ettiğinde iki, hata ettiğinde bir ecir alacağının ${ }^{25}$ belirtilmesi de bu hükmün bir başka yansıması olarak düşünülebilir.

Bu süreçte sahâbenin müstakil içtihadı olmadığından, sonraki dönemlerde görülen haliyle bir ihtilaftan bahsedilemez. ${ }^{26}$ Teşrî sürecinde Hz. Peygamberin söz ve davranışları yanında nasları beyan niteliğindeki açıklamaları da hukukun kaynaklarının oluşması bağlamında önemli bir yer tutmaktadır. ${ }^{27}$

\footnotetext{
19 Şah Veliyyullah Dehlevî, Kitâbu'l-insâf(İstanbul: Hakikat Kitabevi,1994), 2.

20 Hallâf, Hulâsatu't-Teşrîi'l-İslâmî, 289.

21 Ebû Dâvûd Süleyman b. Eş'as es-Sicistânî, es-Sünen, (İstanbul: Çağrı Yayınları, 1992), “Akdiye”, 11.

${ }^{22}$ Ali el-Hafif, Esbâbu İhtilâfil-Fukahâ (Kahire: Dâru'l-Fikri'l-Arabî, ts), 10; Hallâf, Hulâsatu't-teşrî́il'İ̇lâmî, 284.

23 Ebû Dâvûd, "Tahâret”, 126.

24 Beyânûnî, Dirâsât, 23.

25 Buhârî, "ítisâm", 21.

26 Zeydan, el-Medhal, 116.

27 Oğuzhan Tan, "Nevazil Fıkhının Ortaya Çıkışı, Mahiyeti ve Genel Özellikleri”, Fıkıh, ed. İbrahim Çalışkan (Ankara: Ankara Üniversitesi Basımevi, 2009), 283.
} 


\section{Sahâbe Dönemi ve İhtilaf}

\subsection{Sahâbe Döneminin Genel Özellikleri}

İslam hukuk tarihinde Hz. Peygamberin vefatından tâbiîn dönemine kadar devam eden süre, sahâbe dönemi olarak adlandırılmaktadır. Hukukî hayatı şekillendiren nesli dikkate alarak bu dönemi Hz. Peygamberin vefatıyla başlatıp hulefâ-i râşidînin sonuna (41/661), yahut sahabe neslinin sonu olan ikinci hicrî asrın başlarına kadar uzatan hukuk tarihçileri vardır. ${ }^{28}$ Siyasî iktidarı dikkate alan tarihçilere göre hulefâ-i râşidîn veya Emevîlerin sonuna kadar devam etmektedir. ${ }^{29}$ Sahabe dönemini hulefâ-i râşidîn ve sonrası olmak üzere iki ayrı devre olarak ele alan hukuk tarihçileri de vardır.

Sahâbe, nüzûl sürecini yaşamış ve Hz. Peygamberin fiilî örnekliğine şahit olmuştur. Onlar vahyin tanıkları ve gelişen olaylarla birlikte teşrî sürecinin canlı şahitleridir. Bu sürecin sahâbeye kazandırdığı bilgi, tecrübe ve fikhî melekenin değeri yadsınamaz. Bu yüzden onların dinî konulardaki sözlerine ve hüküm verirken benimsedikleri yöntem ve yaklaşım biçimine itibar edilmiş ve sahâbe sözü İslam hukukunun deliller hiyerarşisi içinde yer almıştır.

Hz. Peygamberin vefatından sonra sahâbenin önemli bir kısmı değişik sebeplerle Hicaz dışındaki bölgelere göç etmiş, bulundukları yerlerde dinî konularda sözlerine itibar edilen, kanaatleri geniş kitlelerce benimsenen birer başvuru mercii olmuşlardır. Bulundukları bölgelerin sosyal, iktisadî ve coğrafi özelliklerine göre verdikleri bazı fetva ve kararlarda ihtilaflar ortaya çıkmıştır. ${ }^{30} \mathrm{~Hz}$. Peygamber zamanında sahâbe arasında ilk örnekleri görülen küçük çaplı ihtilaflar, bu dönemde gerçek anlamıyla kendini hissettirmiştir. ${ }^{31}$

Sahâbe dönemindeki siyasî gelişmeler fikhı çok yönlü etkilemiştir. ${ }^{32} \mathrm{~Hz}$. Osman'ın şehit edilmesiyle başlayan ve hulafâ-i râşidîn döneminin sonlarında yaşanan siyasî çalkantılarla devam eden gelişmeler sonucunda Haricîler, Şîa ve sonraki dönemde ehl-i sünnet ve'l-cemaat olarak isimlendirilecek çoğunluk olmak üzere üç grup ortaya çıkmıştır. ${ }^{33}$ Haricîler, siyasî olarak karşı oldukları sahâbenin rivayet ettiği hadislere ve fetvalarına itibar etmemiş ve Müslümanların çoğunluğunun dışında bir hukuk geliştirmişlerdir. ${ }^{34}$ Sadece ehl-i beyt yoluyla gelen ve taraftarları

28 Son sahâbî kabul edilen Ebu't-Tufeyl Âmir b. Vâsıle'nin hicrî yüz senesinde vefat ettiği bilinmektedir. Bkz. Mehmet Efendioğlu, "Sahâbe", Türkiye Diyanet Vakfi İslâm Ansiklopedisi (İstanbul: TDV Yayınları, 2008), 35/491-500.

29 Hayreddin Karaman, İslam Hukuk Tarihi (İstanbul: Nesil Yayınları, 1989), 109.

30 Şah Veliyyullah Dehlevî, Huccetullâhi'l-bâliğa (Beyrut: Dâru'l-Kütübi'l-i̇lmiyye, 1995), 1/263; Muhammed Beyânûnî, Dirâsât fi'l-ihtilâfâti'l-ilmiyye (Kahire: Dâru's-Selâm, 2013), 19; Hallâf, Hulâsatu'tteşrî́i'l-İslâmî, 305.

31 Muhammed Beyânûnî, Fikhu'l-i'tilâf ve'l-ihtilâf (Riyad: Kürsiyyü'l-Emîr Sultan b. Abdil'azîz li'd-dirâsâti'lİslâmiyye el-Muâsıra, 1431), 18.

32 Tâhâ Câbir Alevânî, Edebü'l-ihtilâffi'l-İslâm (Amerika Birleşik Devletleri: Silsiletü Kadâyâ el-Fikri'l-İslâmî, 1987), 75-77.

33 Hallâf, Hulâsatu't-teşrî́i'l-íslâmî, 307-308.

34 Abdulkâdir Ali Hasan, Nazratu'n-âmme fi târîhi'l-fikhi'l-İslâmî (Mısır: Mektebetü’l-Kahire, 1956), 173-174. 
olan sahâbenin rivayet ve fetvalarını kabul eden Şîa da ayrı bir hukuk anlayışını benimsemiştir. ${ }^{35}$ Buna mukabil çoğunluğu oluşturan grup, sahâbe arasında bir ayrım yapmadan rivayet tekniğini esas almış ve siyasî bir tavır içine girmemiştir. İslam hukukunun oluşum sürecinde ortaya çıan bu anlayışlar, ihtilaf bağlamında hükümlere yansıdığı gibi, sonraki dönemleri de çok yönlü etkilemiştir. ${ }^{36}$

Sahâbe, içtihadın göreceli oluşu ve hata ihtimali taşıması sebebiyle, içtihatları sonucu ulaştıkları hükümlerle nasların açık hükümlerini bağlayıclık açısından birbirinden ayrı tutmuşlardır. Hatta bunu açıç̧a dile getirme ihtiyacı hissetmişlerdir. Hz. Ebû Bekir, verdiği hüküm sonrasında "Bu benim görüşümdür, eğer doğru karar verdiysem bu Allah'tandır, hata ettiysem bendendir. Bundan dolayı Allah'tan bağışlanma diliyorum." demiştir. Aynı hassasiyeti taşıyan Hz. Ömer'in, içtihadıyla hüküm verdiği konularda kâtibine, "Bu Ömer'in re'yidir şeklinde yaz" diyerek uyardığı bilinmektedir. ${ }^{37}$ Bu hassasiyeti diğer sahabîlerde de görmek mümkündür.

Sahâbe, içtihadî konularda kendileriyle aynı fikri benimsemeyen kişileri kınamamış, birbirlerine karşı edep ve saygı sınırlarını muhafaza etmişlerdir. İhtilaf ettikleri konularda şûrâ yoluyla birlik sağlama gayretleri olsa da her özel meselede icmâ olması gerektiğini de savunmamışlardır. ${ }^{38}$

\subsection{Sahâbe Döneminde Fıkhın Kaynakları}

Sahâbe, Hz. Peygamberin vefatından sonra hukukî problemleri çözmede öncelikle Kitap ve Sünnet'e, bu ikisinde hükmü bulamadıklarında re'ye başvurmuşlardır. ${ }^{39}$ Hükmü kendi çabalarıyla bulamadıklarında diğer sahâbe ile istişare etmişler, görüşlerin birden çok olması durumunda diledikleri görüşle amel etmişlerdir. $\mathrm{Bu}$ dönemde belli bir sahabînin görüşüne tabi olmak gibi bir gelenek oluşmamıştır. ${ }^{40}$

Hz. Ebû Bekir ve Hz. Ömer, kendilerine bir soru yöneltildiğinde, konuyla ilgili hadis olup olmadığını sormuşlardır. ${ }^{41} \mathrm{~Hz}$. Peygamberden kendilerine bir hadis ulaştığında, bunun gereğine göre amel etmişler ve başka bir istidlâle başvurmamışlardır. Örneğin nineye mirastan verilecek hisse konusunda Hz. Peygamberden bir haber duyan olup olmadığını soran Hz. Ebû Bekir, Muğîre b. Şu'be'nin altıda bir hisse verdiğini haber vermesi üzerine bu konuda başka şahidi olup olmadığını sormuş, Muhammed b. Mesleme'nin de aynı doğrultuda bilgi vermesi üzerine bu yönde hüküm

35 Muhammed Ebû Zehra, Muhâdarât fî usûli'l-Ca'ferî(Mısır: y.y.,1956), 28.

36 Muhammed Hudarî, Târîhu't-teşrî́il-İslâmî (Beyrut: Dâru İhyâi't-Türâsi'l-Arabî, 1960), 134; Kaşif Hamdi Okur, "İslam Hukukunun Oluşumu ve Tarihsel Gelişimi”, İslam Hukukuna Giriş, ed. Hacı Yunus Apaydın (Eskişehir: Anadolu Üniversitesi, 2019), 30.

37 Şemsüddîn Ebû Abdillah Muhammed b. Ebî Bekr İbn Kayyım, İlâmu'l-muvakkû̂n an Rabbi'l-Âlemîn (Beyrut: Dâru'l-Cîl, ts.), 1/39, 54; Zeydan, el-Medhal, 120.

38 Aykut Avc1, "Fıkhi İhtilafların Tarihsel Gelişimi”, Bozok Üniversitesi İlahiyat Fakültesi Dergisi, 8/8 (2015/8), 121.

39 H. Yunus Apaydın, İslam Hukuk Usûlü (Ankara: BİLAY, 2018), 317-318.

40 Mennâu'l-Kattân, Târîhu't-teşrîi'l-íslâmî (Kahire: Mektebetü Vehbe, 1989), 39, 73; Hayreddin Karaman, İslam Hukukunda İctihad (Ankara: Emel Matbaacilik, ts.), 62.

${ }^{41}$ Dehlevî, Huccetullahi'l-bâliğa, 1/262. 
vermiştir. Benzer konularda Hz. Ömer'e nispet edilen birçok olaydan bahsedilmektedir. ${ }^{42}$

İlk iki halifenin yeni ortaya çıkan konularda ihtilafı azaltmak, özellikle kamu hukuku alanında toplum maslahatına uygun doğru kararlar almak amacıyla istişare metoduna başvurmuşlardır. ${ }^{43} \mathrm{~Hz}$. Ömer bu amaçla bir heyet oluşturmuş ve istişare heyeti üyelerinin Medine dışına çıkmalarını sınırlandırmıştır. ${ }^{44} \mathrm{~Hz}$. Ömer'in Irak toprakları hususunda sahâbenin önde gelen fakihleriyle günlerce süren toplantılar gerçekleştirdiği bilinmektedir. ${ }^{45}$ Kur'an'ın belirlediği ve Hz. Peygamberin fiilen uyguladığı şûrâ prensibi, ihtilafları azaltmada etkili olmuş ve bu yöntemle alınan kararlara genelde riayet edilmiştir. İhtilaflı konularda ise görüşlerden birine tabi olunmuştur. ${ }^{46}$

Görüş, düşünce, kıyas ve nasla düzenlenmemiş şer’̂̂-amelî bir meselede ortaya konan kanaat anlamına gelen re'y, ${ }^{47}$ bu dönemden itibaren kullanılmıştır. Hz. Ömer, Abdullah b. Mes'ûd ve Hz. Ali gibi sahabîler re'ye daha çok başvururken, Abdullah b. Ömer, Zeyd b. Sabit gibi kimi sahabîler re'yi daha az kullanmışlardır. Her iki yaklaşımın da Kur'an ve Sünneti birer aslî delil olarak kabul etme hususunda aralarında bir farklılık bulunmamaktadır. Ancak re'y ehli fakihler, bazı sebeplerle re'ye daha çok başvurmuş, hükmün naslarda açıkça bulunmadığı durumlarda hükmün illeti ve maslahat doğrultusunda meselelerin çözümü cihetine gitmişlerdir. ${ }^{48}$

Bu dönemde re'y, Kitap ve Sünnet'te hükmü bulunmayan konularda nasların ve İslam'ın genel ilkelerine uygun şekilde hüküm verme anlamında kullanılmıştır. Sonraki dönemlerde kıyas, istihsan, örf ve maslahat-1 mürsele gibi İslam hukuk usûlünde her biri özel bir delil niteliğindeki hususlar, bu dönemde re'y kavramı içinde fiilen tatbik edilmiştir. ${ }^{49}$

Sahâbe, Kur'an'daki delillerin Hz. Peygamber tarafından nasıl açıklandığını da belirlemeye çalışmıştır. Hadislerin hüküm ortaya koymadaki etkin rolü sebebiyle bu dönemde hadis bilmek, adeta fikıh bilmekle eşdeğer kabul edilmiştir. Fetih hareketleri ile birlikte hadislerde hükmü bulunmayan bazı meseleler ortaya çııınca, içtihatlarıyla hüküm vermişlerdir. Ancak bireysel bir tercih olarak fetva vermede çok istekli davranmamışlar ve daha bilgili olduğunu düşündükleri kişilerin görüşlerine başvurulmasını istemişlerdir. Abdurrahman b. Ebî Leyla, ashâbın bu konudaki sorumluluk bilincini dile getirme bağlamında şöyle söylemektedir: "Bu mescidde

\footnotetext{
42 Dehlevî, Kitabu'l-ínsâf, 3.

43 Kattân, Târîhu't-teşrîi'l-İslâmî,189; Hallâf, Hulâsatu't-teşrî́i'l-İslâmî, 303.

44 Alevânî, Edebü'l-ihtilâf, 71-72.

45 Saffet Köse, “Hz. Ömer’in Bazı Uygulamaları Bağlamında Ahkâmın Değişmesi Tartışmalarına Bir Bakış”, İslam Hukuku Araştırmaları Dergisi 7 (Nisan 2006), 35-43.

46 Hudarî, Târîhu't-Teşrî́il-İslâmî, 122-123.

47 H. Yunus Apaydın, “Re'y”, Türkiye Diyanet Vakfi İslâm Ansiklopedisi (İstanbul: TDV Yayınları, 2008), 35/37.

48 Abdullah Kahraman, İslam Hukukuna Giriş (Ankara: BİLAY, 2019), 130-131.

49 İbn Kayyım, İlâmu'l-Muvakkîn, 1/61, 66; Hayreddin Karaman, İslam Hukuk Tarihi (İstanbul: Nesil Yayınları, 1989), 113.
} 
(Mescid-i Nebebî) Resûlullah'ın ashabından yüz yirmi kişiyle karşılaştım. Onlardan birine bir soru sorulduğunda, başka bir Müslüman kardeşinin bu konuda daha kapsamlı bilgi vereceğini söylerdi." ${ }^{50}$ Sahâbe, hatalı buldukları görüşleri uygun bir üslupla dile getirmekten de çekinmemiştir. ${ }^{51} \mathrm{Bu}$ tutum, sahâbenin hüküm verirken yaklaşım biçimini ve ihtilaflı konularda takındıkları tavrı göstermesi bakımından dikkat çekicidir. Sahâbenin fetva verirken birbirlerine danışmaya önem vermesi de belirtilmesi gereken başka bir husustur. ${ }^{52}$ Sahâbenin hüküm istinbâtında benimsediği prensipler, sonraki dönemler için de yol gösterici olmuştur.

\subsection{Sahâbe Döneminde İhtilaf}

Hz. Peygamberin sağlığında sahâbe arasında yaşanan bazı ihtilafların Allah'ın elçisi tarafından çözüme kavuşturulduğunu belirtmiştik. Hz. Peygamberin vefatıyla birlikte vahiy kesildiği ve ihtilafların çözüm mercii kalmadı̆̆ından, ciddi anlamda ilk ihtilafların baş gösterdiğini söyleyebiliriz. İslam hukuk tarihçileri ilk ihtilafların Hz. Peygamberin vefatı, defnedilmesi ve yerine kimin halife olacağı konusunda gerçekleștiğini ifade etmektedir. ${ }^{53}$

Hz. Ebû Bekir ve Hz. Ömer döneminde izlenen politika gereği sahâbenin yerleşme amaçlı Medine dışına çıkmalarına sınırlama getirilmişken, Hz. Osman döneminde bu kısıtlılığın kaldırılması ve aralarında fikıh ve kıraat âlimlerinin bulunduğu üç yüzü aşkın sahâbenin Basra, Kûfe, Mısır ve Şam gibi şehirlere yerleşmesi, ihtilafı etkileyen unsurlardan biri olmuştur. Bu durum istişare merkezli kararları zayıflatmış, bölgesel ve coğrafi farklılıklara dayalı ihtilafları açığa çıkarmıştır.

$\mathrm{Bu}$ dönemde yaşanan ihtilaf sebeplerini aşağıdaki başlıklar altında ele almak mümkündür:

\subsection{1. İlgili Nas veya Hükme Ulaşmamış Olmak}

İslam topraklarının genişlemesi, görevler veya farklı nedenlerle Medine dışında bulunan bazı sahâbenin nazil olan kimi âyetlerden veya Hz. Peygamberin uygulamalarından haberdar olmaması ihtilaf sebebi olmuştur. ${ }^{54}$

Ebû Hureyre, cünüp olarak sabahlayan kişinin orucunun sahih olmayacağını söylemiştir. Ancak Hz. Peygamberin eşlerinden birinin aksi yöndeki sözleri üzerine bu görüşünden vazgeçmiştir. ${ }^{55}$ Yine mehir tayin edilmeden ölen kadınının durumu Abdullah b. Mes'ûd'a sorulduğunda o, Hz. Peygamberden gelen bir hüküm bilmediği için cevap vermemiştir. Kendisine yöneltilen ısrarlı sorular üzerine bu konuda re'yi ile karar vermiş ve sözü edilen kadına diğer eşlerine verdiği kadar mehir verilmesi

50 Alevânî, Edebü'l-ihtilâf, 124-125.

51 M. Esad Kılıçer, İslâm Fıkhında Re'y Taraftarları (Ankara: Diyanet İşleri Başkanlığı Yayınları, 1994), 36.

52 Abdullah b. Abdülmuhsin et-Türkî, Esbâbu İhtilâfil-fukahâ (Beyrut: Müessesetü'r-Risâle, 1431/2010),144.

53 Alevânî, Edebüll-ihtilâf, 50-52.

54 Ahmed b. Muhammed el-Ensârî, Âsâru ihtilâfi'l-fukahâ fi'ş-şerîa (Riyad: Mektebetü Rüşd, 1996), 25.

55 Bedruddîn Zerkeşî, Hz. Aişe’nin Sahâbeye Yönelttiği Eleştiriler. nşr. Bünyamin Erul (Ankara: Otto, 2010), 67-68. 
gerektiğine hükmetmiştir. Daha sonra Ma'kîl b. Yesâr'ın, Hz. Peygamberin bu konumdaki bir kadın için aynı hükmü verdiğini nakletmesi üzerine bundan büyük bir memnuniyet duymuştur. ${ }^{56}$

Gusleden kadının saç örgülerini çözüp çözmeyeceği konusundaki şu haber de bu konuda güzel bir örnektir. Rivayete göre Abdullah b. Amr, gusleden kadınların saç örgülerini açmaları gerektiğini söylemiştir. ${ }^{57}$ Onun bu sözleri Hz. Aişe'ye ulaştığında, “İbn Amr’a hayret doğrusu! Guslederken kadınların saç örgülerini açmalarını emrediyor. Bari başlarını kazımalarını da söylese ya! Ben Allah Resûlü ile aynı kaptan yıkanıyordum, başımdan üç defa su dökmekten başka bir şey yapmıyordum" demiştir. ${ }^{58}$

\subsubsection{Hadisin Sağlam Bir Kaynaktan Ulaşmamış Olması}

Bazı sahabîlere sahih bir senetle ulaşan hadis, başka bir sahâbîye aynı şekilde ulaşmadığından, söz konusu hadisle amel edip etmeme hususunda farklı uygulamalar ortaya çıkmıştır. Cünüp olan kişinin su bulamadığı takdirde teyemmümle temizlenmiş sayılacağını kabul etmeyen Hz. Ömer, Ammâr'ın bu hükmü Hz. Peygamberden duyduğunu söylemiş olmasına rağmen, bu rivayeti kabul etmemiştir. ${ }^{59}$ Aynı şekilde Fâtıma bt. Kays, üç talakla boşandıktan sonra Hz. Peygamberin kendisine mesken ve nafaka verilmesine hükmettiğini söylemesine rağmen, Hz. Ömer, "Doğru mu yoksa yalan mı söylediğini bilemediğimiz bir kadının sözüyle Allah'ın Kitabındaki hükmü terk edemem" diyerek kadının şahitliğini kabul etmemiştir. ${ }^{60}$

Hadisin Hz. Peygambere aidiyetinden emin olmak için ileri sürülen şartların farklı olması da bir ihtilaf sebebi olmuştur. Bu kapsamda Hz. Ebû Bekir'in, râvînin şahit getirmesini istediği, Hz. Ömer'in delil talebinde bulunduğu, Hz. Ali'nin râviye yemin ettirdiği bilinmektedir. ${ }^{61}$

\subsubsection{Farklı Anlayışlar}

Sahâbe, Hz. Peygamberin bazı söz ve uygulamalarını kendi anlayışları çerçevesinde uygulamaya koymuştur. Bu durum aralarında bilgi, anlayış ve değerlendirme becerisi bakımından farklılık bulunan sahâbe arasında ihtilaf sebebi olmuştur. Hz. Ebû Bekir'in halifeliği döneminde bazı kişiler zekât vermekten imtina ettiklerinde, halifenin zekâtla namazın birbirinden ayrılamayacağını söylemesi ve zekâtın fakirin hakkı olduğunu ileri sürerek, bu konuda gerektiğinde kendileriyle savaşacağını ifade etmesi bu konuda bir örnektir. Hz. Ömer'in, iman edenlerin canlarının dokunulmaz

\footnotetext{
56 Ebû Dâvûd, "Nikâh”, 30, 31; İbn Kayyım, İlâmul-muvakkîn, 1/57,63.

${ }^{57}$ Ali el-Hafîf, Esbâbu ihtilâfil-fukahâ, 32.

58 Ebu'l-Huseyn Müslim b. el-Haccâc, el-Câmi’u's-sahîh, (İstanbul: Çağrı Yayınları, 1992), “Hayız”, 59. Bu konudaki tartışmalar için bkz. Zerkeşî, Hz. Aişe'nin Sahâbeye Yönelttiği Eleştiriler, 64.

59 Muhammed b. Ali Şevkânî, Neylü'l-evtâr şerhu münteka'l-ahbâr min ehâdîs-i Seyyidi'l-Ebrâr (Kâhire: Dâru'lHadîs, ts.), 1/256-257.

60 Hudarî, Târîhu't-teşrîil-íslâmî, 120-121.

61 Hallâf, Hulâsatu't-teşrî̀il-İslâmî, 302.
} 
olduğunu ifade eden hadisi dile getirerek itirazda bulunmasına rağmen halife bu fikrinden vazgeçmemiştir. Sonunda Hz. Ömer de "Allah, onlarla savaşma konusunda Ebû Bekir'in zihnini açmış ve ona gerçeği anlama imkânı vermiştir. Ben de onun doğru olduğunu anladım" diyerek halifenin haklı tutumunun yanında olmuştur. ${ }^{62}$

Yine Ebû Hureyre ile Abdullah b. Ömer, Hz. Peygamberin Mina ile Mekke arasında Muhassab denilen mevkide konaklamasını, ibadet niteliği taşıdığı kanaatiyle sünnet olarak değerlendirmişlerdir. Hz. Aişe ve Abdullah b. Abbas ise bunun beșerî bir ihtiyaçtan kaynaklandığını ve sünnet olmadığını dile getirmişlerdir. Konuya ilişkin bir başka örnek de remel uygulaması hakkındadır. Abdullah b. Abbas, tavaf esnasında remel yapmayı Müslümanların Medine'de zayıf ve güçsüz duruma düştügünü iddia eden müşriklere karşı güçlü görünmek amacıyla geçici olarak yapıldığını ve Sünnet olmadı̆̆ını ifade etmiştir. ${ }^{63}$

Hz. Ömer'in hilafeti döneminde Irak, Suriye ve Mısır topraklarının fethi sonrasında gaziler, önceki uygulamalar doğrultusunda fethedilen arazilerin kendi aralarında bölüştürülmesini talep etmişlerdir. Müslümanların maslahatı açısından bu fikri doğru bulmayan halife, söz konusu arazilerin bölge halkına bırakılmasının daha doğru olacağını ifade etmiştir. Hz. Ali, Hz. Osman, Talha ve Abdullah b. Ömer de aynı fikri paylaşmakla beraber, içlerinde Zübeyr b. Avvam'ın da bulunduğu başka bir grup sahâbe, bu toprakların gaziler arasında paylaştırılmasını istemiştir. Ensar'dan on kişi ile durumu istişare eden Hz. Ömer, arazilerin gazilere dağıtılmamasında karar kılmıştır. Böylece bahse konu toprakların mülkiyeti devlete ait olmuş, arazi sahipleri de bu topraklardan yararlanma karşılığında "haraç" vergisi ödemekle yükümlü kılınmıştır. ${ }^{64}$ Bu tasarruf, Osmanlıdaki "mîrî arazi” uygulamasına da temel teşkil etmiştir. ${ }^{65}$

Yine bu dönemde nasların lafzı ile maksat ve ruhu arasında dengenin dikkate alındığ $1{ }^{66}$ nasların, zaman ve çevresel faktörlere bağlı olarak illetlerinde yaşanan değişim sebebiyle gâî yoruma tabi tutulduğu görülmektedir. Müellefe-i kulûba zekâttan hisse verilmesi uygulamasının kaldırılması, Hz. Ömer'in bazı idarecilerine ehl-i kitap kadınlarla evlenme konusunda kısıtlama getirmesi ve kıtlık yılında hırsızlık cezasını tatbik etmemesi gibi uygulamalar bu kapsamdaki örnekler arasında sayılabilir. ${ }^{67}$

62 Mahmud Abdullatîf, el-İhtilâfâtu'-fikhiyye, 114.

63 Dehlevî, Huccetullâhil-bâliğa, 1/264.

64 Yakûb b. İbrahim Ebû Yûsuf, Kitâbu'l-Harâc (Mısır: y.y., 1352),75, 83, 85; Ebû Bekir Ahmed b. Ali er-Râzî el-Cessâs, Ahkâmu'-Kur'an (Beyrut: Dâru ihyâi't-Türâsi'l-Arabî, 1405/ 1985), 5/318-320; Hudarî, Târîhu'tteşrîili-̇̇slâmî, 122-124.

65 Hamdi Döndüren, “Sosyal Değişme Karşısında İslam Hukuku ve Yeni Yaklaşımlar”, İslam Hukuku Araştrrmaları Dergisi 1 (2003), 35.

66 Osman Şahin, "Sahabe ve Tâbiûn Müçtehitlerinin Yeni Gelişmeler Karşısındaki Tutumlarının Hukuk Metodoloji Açısından Analizi”, Oş Devlet Üniversitesi Illahiyat Fakültesi İlmi Dergisi 9-10 (2006), 61.

${ }^{67}$ Konuyla ilgili kapsamlı değerlendirme için bk. Köse, "Hz. Ömer’in Bazı Uygulamaları Bağlamında Ahkâmın Değişmesi Tartışmalarına Bir Bakış",13-50. 
Kur'an ve Sünnetin hükme delaleti her zaman aynı kesinlikte olmadı̆̆ından, bazı âyetlerdeki ifadelerin hangi anlama geldiği hususunda da ihtilaf yaşanmıştır. Boşanmış kadınların iddet sürelerini belirleyen âyette ${ }^{68}$ geçen kur' lafzı hem temizlik hem de hayız hali anlamına geldiğinden, sahâbeden her iki görüşü de benimseyenler olmuştur. ${ }^{69}$

\subsubsection{Farklı Yorumlamalar}

Hz. Peygamber, Hendek savaşı sonrasında ashabında hiç kimsenin Benî Kureyza'ya varmadan ikindi namazını kılmamasını istemiştir. Kimi sahabîler, Hz. Peygamberin bu sözünü bir an önce Benî Kureyza'ya ulaşılması şeklinde anlamıştır. Bazıları da sözün zahirine göre karar vermişlerdir. Durum Hz. Peygambere arz edildiğinde, her iki görüşü de tasvip etmiştir. ${ }^{70} \mathrm{Bu}$ iki anlayış tarzı, daha sonraki dönemlerde nasların lafzî (literal) ve makâsıd merkezli (gâî) yorumu olarak iki farklı ekolün temsili şeklinde devam etmiştir. İbn Kayyım el-Cevziyye gibi bazı âlimler, zâhirî ve kıyas merkezli yaklaşımın kaynağını bu hadiseyle ilişkilendirmektedirler. ${ }^{71}$

Âyetlerin nüzûl süreci, nesh ve tahsis gibi konularla, nasların yoruma açık olup olmaması gibi pek çok etken sebebiyle, aynı naslar üzerinden farklı sonuçlara ulaşılabilmiştir. Bu durum da ihtilafları artırmıştır. ${ }^{72}$

\subsubsection{Unutma ve Yanılmalar}

Hz. Ömer ve oğlu Abdullah'ın, Hz. Peygamberin, “Ölü, ailesinin ağlamasından dolayı azap görür" hadisini rivayet ettiğini işiten Hz. Aişe, onların bazı şeyleri unuttuklarını ifade ederek şöyle demiştir: "Resulûllah, ölen bir Yahudi kadının akrabalarını ağlar vaziyette görünce şöyle buyurdu: 'O kabrinde azap çekiyor, bunlar da (onun ölümü sebebiyle) ağlıyor.” Burada râvî, ölen kişinin azap çekmesinin, yakınlarının ağlamasından dolayı meydana geldiği şeklinde yanlış bir anlayışa kapılmıştır. Yine Hz. Aişe, Hz. Peygamberin Recep ayında umre yaptığını söyleyen Abdullah b. Ömer'in yanıldığını ifade etmiştir. ${ }^{73}$

İhtilam olan kişinin cünüp olarak sabahlaması halinde orucunun sahih olmadığını söyleyen Ebû Hureyre, ${ }^{74}$ Hz. Aişe'den rivayet edilen bir hadisten, Hz. Peygamberin aksi yöndeki uygulamasını öğrenince görüşünden vazgeçmiştir. ${ }^{75}$

Sahâbe döneminde ihtilaf azdır. Sahâbenin hulefâ-i râşidîn döneminde genelde Medine'de bulunması ve yeni ortaya çıkan meselelerde fikir birliği etmenin bu

\footnotetext{
68 el-Bakara 2/228.

69 Hudarî, Târîhu't-teșrî́il-İslâmî,125.

70 Muhammed b. İsmail el-Buhârî, el-Câmi'u's-sahîh, (İstanbul: Çağrı Yayınları, 1992), "Meğaẑ̀”, 30; Ebu'lHüseyin Müslim b. Haccâc, el-Câmi u's-sahîh, (İstanbul: Çağrı Yayınları, 1992), "Cihad ve's-Siyer”, 23.

71 Ensârî, Âsâru ihtilâfi'-fukahâ fi'ş-şerîa,33; Okur, "İslam Hukukunun Oluşumu ve Tarihsel Gelişimi”, 29.

72 Hallâf, Hulâsatu't-teşrîi'l-İ́lâmî, 305.

73 Dehlevî, Huccetullâhi'l-bâliğa, 1/266.

74 Ali el-Hafîf, Esbâbu ihtilâfil-fukahâ, 33.

75 Müslim, "Sıyâm", 79.
} 
süreçte kolay olması ihtilafı azaltan unsurlardan biri olmuştur. Özellikle Hz. Ömer döneminde Şûrâ yöntemiyle belirlenen kararlar büyük ölçüde kabul görmüş ve ihtilafların azalmasında etkili olmuştur. ${ }^{76}$ Hadis kaynaklı ihtilafların az oluşu, sahâbenin fetva vermede temkinli davranması, devlet yönetiminin karar ve uygulamalarında fikhî hükümleri dikkate alması da ihtilafı azaltan bir başka unsur olmuştur. ${ }^{77}$

Genel olarak ifade etmek gerekirse, sahabe dönemi ve tâbiîn fukahasının; adalet mekanizmasından medenî hukuka, ekonomik ve iktisadî yapıdan ibadetlere kadar geniş yelpazedeki yeni gelişmelere ilişkin görüş ve içtihatları fikhın gelişmesine katkı sağladığı gibi, ihtilaf olgusunu da çok yönlü etkilemiştir. Vergi sisteminin yeniden düzenlenmesi, yargıda şahitlerin tezkiyesi, narh konulması, üç talakla ilgili düzenleme ve Cuma namazında iç ezanı gibi hususlar, bu gelişim ve etkileşimin sınırlı sayıdaki örnekleridir. ${ }^{78}$

\section{Tâbiîn Dönemi ve İhtilaf}

\subsection{Tâbiîn Dönemine Genel Bakış}

Tâbiîn döneminin, bazı farklı yaklaşımlar bulunmakla birlikte sahabe devrinin bitmesinden Emevî devletinin yıkılışına kadar (132/750) devam ettiği kabul edilmektedir. ${ }^{79}$ Fikhı sahâbeden öğrenen tâbiîn, onlardan aldıkları metod üzerine devam etmişlerdir. Sahâbe döneminden farklı olarak, bu dönemde farazî meseleler üzerinde de fikhî görüş serdedilmiştir. Fıkhın gelişmesi ve yeni meseleler üzerinde fikir üretimi bağlamında önemli katkılar sağlayan farazî fikha, Mâlikî ve Şâfiî fakihleri de başvurmakla birlikte, Irak fakihleri arasında daha yaygındır. ${ }^{80}$ Farazî fikıhla o kadar çok içtihadî hüküm ortaya çıkmıştır ki bu durum, hicrî dördüncü asırda artık her içtihadî meselenin bir karşılığı ve çözümü olduğu ve yeni içtihada gerek kalmadı̆̆ı şeklinde bir kanaatin oluşmasına zemin hazırlamıştır.

\subsection{Tâbiîn Döneminde Fikhın Kaynakları}

Tâbiîn döneminde fikhın kaynakları Kitap, Sünnet, sahâbenin istişare temelli kararları ve içtihattır. Tâbiîn, sahâbenin görüşlerini dikkate almış ve ihtilaflı konularda ihtilafın arasını bulmaya çalışmıştır. ${ }^{11}$ Bunun mümkün olmaması halinde sahâbeden birinin görüşünü benimsemiş veya tâbiîn âlimlerinin görüşleri doğrultu-

76 Şahin, "Sahabe ve Tâbiûn Müçtehitlerinin Yeni Gelişmeler Karşısındaki Tutumlarının Hukuk Metodoloji Açısından Analizi", 50.

77 Alevânî, Edebü'l-ihtilâf, 48; İbrahim Çalışkan, "Fıkıh Mezheplerinin Oluşum Süreci ve Fakihler Arasındaki Fıkhi İhtilafların Sebepleri”, Fıkıh. ed. İbrahim Çalışkan (Ankara: Ankara Üniversitesi Basımevi, 2009), 41.

78 Bu konuda kapsamlı bilgi ve değerlendirmeler için bk. Şahin, "Sahabe ve Tâbiûn Müçtehitlerinin Yeni Gelişmeler Karşısındaki Tutumlarının Hukuk Metodoloji Açısından Analizi”, 50-58.

79 Abdullah Kahraman, İslam Hukukuna Giriş (Ankara: BİLAY, 2019), 117.

80 Ekrem Buğra Ekinci, İslâm Hukuku Tarihi (İstanbul: İstanbul Arı sanat Yayınları, 2006), 70.

81 Alevânî, Edebüllihtilâf, 72-73. 
sunda hareket etmiştir. Medine fakihleri Hz. Aişe, Hz. Ömer, Abdullah b. Ömer, Zeyd b. Sabit'ten rivayet edilen fetvalara; Irak fakihleri Abdullah b. Mes'ûd, Hz. Ali, Ebû Musa el-Eş'arî ve Enes b. Mâlik'in; Şam fakihleri ise Ebu'd-Derdâ, Muâz b. Cebel ve Ubâde b. Sâmit gibi sahâbenin içtihatlarından istifade etmişlerdir. ${ }^{82}$ Ancak tamamıyla bir sahabîye bağlı kalmak gibi bir anlayış söz konusu olmamıştır. ${ }^{83}$ Tâbiîn dönemi, dinamik fikhî yapısıyla İslam hukuk ekollerinin oluşmasına zemin hazırlamıştır. ${ }^{84}$ Tâbiîn fukahası, görüşleri, uygulamaları ve fıkhî kazanımları ile kendilerinden sonraki nesil için zengin bir ilmî miras bırakmıştır.

\subsection{Tâbiîn Döneminde İhtilaf}

Bu dönemde ortaya çıan ihtilaflar daha çok mekân ve bölgeye dayalı ithilâflardır. Sözün hakikat veya mecazî anlamda kullanılması, hadisin bilinip bilinmemesi, hadisin sıhhati, içtihat bilgi ve usûlünün farklılı̆̆ı ve sosyal çevre da başlica ihtilaf sebepleri arasında zikredilmektedir. ${ }^{85}$ Tâbiînin ihtilaf sebepleri bağlamında başlıca şu hususları zikredilebiliriz:

\subsubsection{Fetihlerle Birlikte Ortaya Çıkan Yeni Kültür ve Anlayışlar}

İslam topraklarının genişlemesiyle birlikte, farklı kültür ve geleneklere sahip milletlerin artması, yeni anlayışları ve yaşantı tarzlarını beraberinde getirmiştir. Sahâbe ve tâbiîn fakihlerinin, bulundukları yerlerin şartlarını ve ihtiyaçlarını dikkate alarak verdikleri hükümler, çoğu zaman birbirinden farklı olmuştur. Özellikle Hz. Ömer'in hilafeti döneminde aktif olarak uygulanan ve ihtilafları azaltan şûrâ içtihadının bu dönemde mümkün olmaması da ihtilafların artmasında başka bir etkendir.

Bu dönemin göze çarpan bir başka özelliği, her bölgenin fakihleri etrafında oluşan tâbilerinin ortaya çıkmasıdır. Şöyle ki halk, bulunduğu yerde güvendiği belli kişilerin görüşlerine itimat etmiş ve onların fetvalarıyla amel etmiştir. Başka kişilere de sorma ihtiyacı hissetmemiştir. Bu durum her bölgede belli fakihleri ön plana çıkarmış ve o fakihlerin görüşleri etrafında bir yoğunluk oluşmuştur. ${ }^{86}$ Medine halkı çoğunlukla Abdullah b. Ömer, Abdullah b. Abbas ve öğrencileri Atâ b. Ebî Rabah, Tâvus b. Keysan gibi fakihlere tabi olmuştur. Basra'da Enes b. Malik, Ebû Mûsâ elEş'arî, Hasan el-Basrî, Muhammed b. Sîrîn etkili olmuştur. Kûfe'de Abdullah b. Mes'ûd ve tâbiîn fakihlerinden Alkame b. Kays, Esved b. Yezid ve İbrahim en-Nehâ̂ ön plana çıkmıştır. Mısır'da Abdullah b. Amr b. el-As, Şam'da ise sahâbeden Muaz b.

\footnotetext{
82 Ömer Nasuhi Bilmen, Hukukı İslâmiyye ve Istılahatı Fıkhiyye Kamusu (İstanbul: Bilmen Yayınevi, 1985), $1 / 310$.

83 Avc1, Fikhi İhtilafların Tarihsel Gelişimi, 125.

84 Ahmed Hassan, İslam Hukuk Ekollerinin Doğuşu, çev. Ali Hakan Çavuşoğlu-Hüseyin Esen (İstanbul: İz Yayıncılık, 1999), 44-45.

85 Karaman, İslam Hukuk Tarihi,172.

86 Muhammed Ebû Zehra, Târîhu'l-mezâhibil'İslâmiyye fi's-siyâse ve'l-akâid ve târîhi'l-mezâhibi'l-fikhiyye (Kahire: Dâru'l-Fikri'l-Arabî, ts.), 270; Türkî, Esbâbu ihtilâfi'l-fukahâ, 49.
} 
Cebel ve Ubâde b. Sâbit'in yanı sıra, tâbiînden Ömer b. Abdülaziz gibi şahsiyetler öne çıkmıştır. ${ }^{87}$

\subsubsection{Re'y ve Hadis Ekollerinin Etkisi}

F1khî problemleri çözmede bir yaklaşım biçimi olarak, re'y ehli diye bilinen fakihlerin belli sebeplerle re'ye daha çok başvurması, buna mukabil ehl-i hadis diye isimlendirilen fakihlerin ise ağılıklı olarak nasların zahiri ile yetinmesi ve bir zorunluluk olmadıkça re'ye başvurmaması da ihtilafı etkileyen unsurlardan biri olmuştur. Her iki yaklaşımın ortaya çıkmasında re'y ekolünün merkezi kabul edilen Kûfe'nin sosyal yapı, örf ve adetlerle hareketli yapısının daha karmaşık olması, buna mukabil hadis ekolünün merkezi sayılan Medine'nin sosyal ve kültürel yapısının daha sade olması gibi faktörlerin etkili olduğu belirtilmiştir. Ancak hadis ekolü ile özdeşleştirilen Hicaz'da Rebîatü'r-re'y gibi re'y taraftarı olan fakihler, re'y taraftarlarının merkezi olan Irak'ta da Şâ'bî gibi hadis ekolüne mensup fakihlerin bulunduğunu ifade etmemiz gerekir. ${ }^{88}$

Irak ekolünü bu yönelişe sevk eden nedenlerden başında şeriatın akla hitap ettiği ve akılla hiçbir şekilde çelişmeyeceği düşüncesi gelmektedir. Onlara göre Kur'an ve Sünnet'teki hükümler, belli amaçları gerçekleştirmek üzere sebep ve illetlere dayandırılmıştır. Şeriatın naslarını bu ilke çerçevesinde anlamaya çalışan Irak ekolü, nasların sadece zahirî anlamı ile yetinmeyip, nüzûl ve vürûd sebeplerini, illet ve gayelerini dikkate alan bir anlayışı benimsemişlerdir. Bu anlayışın bir yansıması olarak, fitır sadakasında verilmesi gereken buğday veya hurmanın bizatihi kendisinin verilebileceği gibi, kıymetinin de verilebileceği kanaatindedirler. Çünkü fitır sadakasından maksat, fakirin ihtiyacını gidermektir. Bu maksat malın aynını vermekle gerçekleşeceği gibi, kıymetini vermekle de gerçekleşir. Aynı hüküm, zekât malları için de geçerlidir. ${ }^{89}$

Görüldüğü gibi Irak ekolü, nasların lafzî (literal) anlamları kadar gözetilen amaçları (gâî yorum) da dikkate alan bir anlayışı benimsemişlerdir. Hicaz ekolü ise daha çok nasların zahirî anlamları ile amel etmekle yetinmeyi tercih etmişlerdir. Bunun bir sonucu olarak, az önce belirttiğimiz sadaka-i fitır ve zekât örneklerinde, belirlenen ölçüde malın aynını vermenin gerekliliğine hükmetmişlerdir. Onlara göre bu malların kıymetini vermekle sorumluluk yerine getirilmiş olmaz. ${ }^{90}$

Hukuk tarihçilerinin re'y ve hadis ekolleriyle ilgili az önce ifade ettiğimiz yaygın değerlendirmelerine karşın, bazı İslam hukukçuları bu ayrımın fikhî değil itikadî olduğu kanaatindedir. Şöyle ki, re'y ehli olarak bilinen müçtehitler, re'yin geçerli olduğu konuları, prensip itibarıyla diğerlerinden daha dar tutmaktadırlar. Söz geli-

87 Mahmud Abdullatîf, el-îhtilâfâtu'l-fikhiyye, 115.

88 M. Esad Kilıçer, "Ehl-i Re'y", Türkiye Diyanet Vakfi İslâm Ansiklopedisi (Istanbul: TDV Yayınları, 1994),10/520523.

${ }^{89}$ Ebû Zeyd ed-Debûsî, Te'sîsü’n-nazar (İstanbul: Eda Neşriyat, 1990), 112.

90 Çalışkan, "Fıkıh Mezheplerinin Oluşum Süreci", 47. 
mi Hanefîler, mukadderât denilen belirlenmiş miktarlar, hadler ve ruhsatlar gibi konularda kıyasa başvurulamayacağı görüşündedirler. Buna mukabil diğer müçtehitler, ta'lîl edilebildiği ölçüde bu konularda da içtihat ve kıyasa başvurmaktadırlar. Yine Irak bölgesinde yeterince hadis bulunmadığı bilgisi doğru olmadığı gibi, ehlhadis ve ehl-i re'y ayrımında Hicaz bölgesi ve Irak bölgesi ayrımı da isabetli değildir. Birçok âlime göre ehl-i hadîs, fikhî değil, kelâmî ekoller arasında sayılmakta, ehl-i re'y kavramı da itikadî bir duruşu ifade etmektedir. ${ }^{91}$

\subsubsection{Delil ve İlke Kaynaklı Fıkhî İhtilaflar}

Sarîh bir nassın bulunmaması halinde kaynak değeri ve delil olarak başvurabilme şartları fakihler arasında tartışmalı olan kıyas, örf, istihsan ve maslahatı mürsele gibi delillerin hüküm istinbatında kullanılıp kullanılmaması da ihtilaf sebepler arasındadır. Ayrıca nassın zahirine veya maksadına göre hüküm verme, hukukî işlemlerin geçerliliğinde zahirî şartları dikkate alma veya niyeti gözetme gibi yaklaşımlar da ihtilaf olgusunu etkilemiştir.

\subsubsection{Sünnet Kaynaklı İhtilaflar}

$\mathrm{Bu}$ dönemde sahâbe ve tâbiîn âlimlerinin kendilerine yöneltilen sorulara hadisler üzerinden cevap vermesi, hadis rivayetini artırmıştır. Hadis bilgisi birbirinden farklı olan kişilerin verdiği cevaplar bir ihtilaf sebebi olmuştur. Yine bazı fırka ve gruplar kendi görüşlerinin doğruluğunu ispat etmek, kimileri de ırkını, mesleğini ve kanaatini desteklemek amacıyla hadis uydurmuştur. Alimler, Hz. Peygambere yalan isnad edilmesini engellemek, Hz. Peygambere aidiyeti sorunlu hadislerle hüküm vermemek ve hadisler üzerinden oluşabilecek yanlış algı ve hükümlere fırsat vermemek için bazı şartlar ileri sürme ihtiyacı hissetmişlerdir. Bu durum hadislerin sübûtu yanında, amel edilme şartları ve yoruma açık olup olmaması (delâlet) gibi pek çok açıdan ihtilafı beraberinde getirmiştir. ${ }^{92}$

\subsubsection{Dil ve Coğrafya Kaynaklı İhtilaflar}

Özellikle mevâlînin (Arap olmayanlar) İslam'a girmesiyle birlikte Müslümanlar arasında dil, kültür, örf ve adetlerin sayısı çoğalmıştır. Bunlar içinden fikıh, hadis, tefsir gibi alanlarda söz sahibi alimler yetişmiştir. İslam toplumundaki bu çeşitlilik, sosyal alanda bir canlılık oluşturmuştur. Kur'an ve Sünnetin anlaşılması yanında, bölgesel örf ve adetlerle çevresel faktörlere bağlı sorunlara yönelik çözüm arayışları artmıştır. ${ }^{93}$ Örneğin Irak bölgesinin dinamik sosyal yapısı ve farklı kültürlerin kavşak noktasında yer alması, re'y ve kıyasa daha çok başvurmayı gerekli kılmıştır. Bu

91 Kapsamlı bilgi ve değerlendirmeler için bk. Abdurrahman Haçkalı, “Ehl-i Hadis- Ehl-i Re’y Ayrışması Fıkhî mi, İtikâdî mi?”, İslam Hukuku Araştırmaları Dergisi 2 (2003), 59-68.

92 Bu konuda kapsamlı değerlendirmeler için bk. Muhammed Avvâme, Eserüll-hadîsi'ş-şerîf fì ihtilâfileimmetil-fukaha (Beyrut: Dâru'l-Beşâir el-İslâmiyye,1997), 109-128.

93 Mahmud Abdullatîf, el-ìhtilâfâtu'l-fikhiyye, 115. 
durum re’ye dayalı fikıh ekolünü beslemiş, düşünceyi geliştirmiş ve farklı bakış açılarını ortaya çıkarmıştır. Aynı zamanda ihtilafları da beraberinde getirmiştir. ${ }^{94}$

\section{Müçtehit İmamlar Dönemi ve İhtilaf}

\subsection{Döneme Genel Bakış}

Hicrî ikinci yüzyılın başlangıcından dördüncü yüzyılın ortalarına kadar devam eden bu dönemde, büyük müçtehitler yetişmiştir. Günümüzde varlığını sürdüren yaygın fikıh mezhepleri bu dönemde teşekkül etmiştir. Fıkhın tedvin edilmesiyle birlikte, mezheplere ait görüşler ortaya konmuştur. F1kha süreklilik kazandıran istinbât metotları netleşmiştir. Fıkıh ve fıkıh usûlüne ilişkin eserler kaleme alınmıştır. Bütün bu gelişmeler daha sistemli bir fikıh eğitimini beraberinde getirmiştir. "Mezheplerin teşekkül dönemi" ve "fikhın olgunluk çağı" olarak da nitelendirilen bu dönem, tâbiîn ile tebe-i tâbiîn neslini içine alan Abbâsî hilâfetine denk düşmektedir.

Abbâsî devlet ricalinin din politikalarının bir yansıması olarak âlimlere yakın durması ve tasarruflarını İslamî ilke ve esaslar çerçevesinde şekillendirme çabaları, fikhın gelişmesini olumlu yönde etkilemiştir. ${ }^{95}$ İmam Ebû Yusufun, Harun er-Reşîd döneminde baş kadılık görevine getirilmesi ve ondan devletin siyaset ve ekonomi alanlarında dikkate alması gereken hususlara ilişkin bir kitap yazmasını istemesi bu kapsamda değerlendirilebilir. ${ }^{96}$ Halife Mansur ve Harun er-Reşîd'in, İmam Malik'in elMuvatta' isimli eserini kanun kitabı olarak kabul etme düşünceleri de bu yönelişin bir başka yansımasıdır.

İslam ülkesinin sınırlarının İspanya ve Çin'e kadar ulaştığı bu dönemde, sosyal ve kültürel hareketlilik artmıştır. Kur'an ve Sünnet'e ilişkin kapsamlı yorumlar, sahâbe ve tâbiîn fakihlerinin içtihatlarından oluşan zengin birikim, İslam fikhının sistemleştirilmesinde güçlü bir veri oluşturmuştur. Sonuçta, döneme isimleri verilecek olan güçlü fakihler yetişmiş ve mezhepler ortaya çıkmıştır. Bu dönemde Kur'an ve Sünnet'in yanı sıra, sahâbenin ittifak halinde olduğu hükümler (sahâbe icmâı) ve sahâbenin bireysel içtihatları hukukun kaynakları arasında yer almıştır. Re'y içtihadı sistemleşerek kıyas, istihsan, 1stıslah gibi kısımlar halinde incelenmiş, her bir bölümün kaynak değeri ayrıca değerlendirilmiştir. ${ }^{97}$

Tâbiîn döneminde temel eğilimler etrafında bir ekolleşme yaşanırken, bu dönemde söz konusu ekoller içinden "mezhep" adıyla şahıs merkezli yeni bir hukukî yapılanma ortaya çıkmıştır. Mezhep imamlarının görüşleri ilk dönemden itibaren talebeleri tarafından öğrenilmekte ve paylaşılmakta ise de bu dönemde, bir imamın fıkhın bütün konularına ilişkin görüşlerinin toplanması, belli bir sistematik içinde

94 Noel J. Coulson,İslam Hukuk Biliminde İhtilaf ve Gerilimler, çev. Ferhat Koca (Ankara: Ankara Okulu Yayınları, 2016), 50; Çalışkan, “Fıkıh Mezheplerinin Oluşum Süreci”, 42.

95 Nahide Bozkurt, Abbâsîler (750-1258). (Ankara: Türkiye Diyanet Vakfi Yayınları, 2018), 41, 43, 62.

96 Salim Ögüt, “Ebû Yûsuf”, Türkiye Diyanet Vakfi İslâm Ansiklopedisi (İstanbul: TDV Yayınları, 1994), 10/264.

97 Okur, "İslam Hukukunun Oluşumu ve Tarihsel Gelişimi”, 33. 
tasnif edilmesi ve usûl kurallarıyla tahkim edilmesi gündeme gelmiştir. Önceki dönemlerde fikhî faaliyetler bir nevi pratik ihtiyaçları karşılama amacına matuf iken, bu dönemde özellikle Hanefî mezhebinde farazî fıkıh konularına yer verilmiştir. ${ }^{98}$

\subsection{Dönemin Fıkıh Açısından Özellikleri}

Bu dönem fikhın gelişim sürecidir. Bu gelişimin sebepleri şöyle açıklanabilir:

1. Sahâbe, hükümlere kaynak ararken Kur'an ve Sünnet'e, tâbiîn fukahası bunlara ilaveten sahâbenin söz ve davranışlarına başvurmuştur. Tebe-i tâbiîn döneminde tâbiînin sözleri de buna eklenmiş ve fikıh malzemesi çoğalmıştır.

2. Re'y'e sıkça başvuran fakihlerin, yaşanmış olaylar yanında, farazî meseleler hakkında da hüküm vermesi fikhın alanını genişletmiştir. Bu durum doğal olarak bazı ihtilafları beraberinde getirmiştir. ${ }^{99}$ Başlangıçta Irak fukahasının başvurduğu bu yola daha sonraları Şâfiî ve Mâlikî fukahası da dâhil olmuştur.

3. Yeni Müslüman olan milletlerin artmasıyla, farklı kültür, anlayış ve şartlara dayalı ortaya çıkan sorunlar, her bölgede ön plana çıkan fakihlere arz edilmiştir. İran örf ve âdetin bulunduğu Irak'taki problemler Ebû Hanife'ye; ağırlıklı olarak Bizans hukuk ve kültürünün etkisinde olan Suriye'deki sorunlar Evzaîye; Mısır ve Bizans etkisinde bulunan Mısır ve çevresindeki konular Leys b. Sa'd ve İmam Şâfiî̀ye; Hicâz örf ve adetlerinin yoğun olduğu meseleler de İmam Mâlik'e arz edilmiştir. Bu imamların verdiği hükümler genelde belirleyici olmuştur. Bu durum bölge içi ihtilafı azaltmakla birlikte, farklı şartları haiz bölgeler arasındaki ihtilafları açı̆̆a çıkarmıştır. ${ }^{100}$

4. Bu dönemde ilmî seyahatlerle sağlanan görüş alışverişleri, mezheplerin dayandığı ilke ve usûllerin yakından tanınmasına ve bölgesel farklılıklara dayalı fikhî problemlerin çözümüne katkı sağlamıştır. İlmî seyahatler, ihtilaf sebeplerini yakından tanımada önemli bir işlev görse de mekân ve coğrafya faktörüne bağlı fikhî ihtilaflar, önde gelen ihtilaf sebeplerinden biri olarak varlığını sürdürmüştür.

5. Fikhın yazılı kaynaklarda derlenip sistematik bir şekilde tedvini, fikhın gelişmesinde etkili olmuştur. İmam Muhammed'in el-Mebsût ve el-Âsâr', İmam Ebû Yusufun Kitâbu'l-Harâc, İmam Şâfiî̀nin el-Ümm adlı eseriyle, İmam Mâlik'in elMuvatta' adlı eserleri bu dönemde yazılmışlardır. Yine içtihatların naslarla bağlantısını kurma ve görüşlerin kendi içinde tutarlılığını sağlama amacını taşıyan fikıh usûlü bu dönemde tedvin edilmeye başlanmıştır. İlk örneğini Şâfiî̀nin er-Risale isimli eserinde gördüğümüz tedvin süreci, tüm usûl konularını kapsayacak şekilde hicrî dördüncü asrın başlarında ortaya çıkmıştır. ${ }^{101}$

Fukaha arasında ihtilafların artması, bunlara ilişkin münakaşa ve eleştiriler, her bir fakihin görüşünü temellendirdiği usûl ve ilkelerin belirlenmesi ihtiyacını

\footnotetext{
98 Okur, "İslam Hukukunun Oluşumu ve Tarihsel Gelişimi”, 34.

99 Mahmud Abdullatîf, el-ihtilâfâtu'l-fikhiyye, 116.

100 Kahraman, İslam Hukukuna Giriş, 129

101 Okur, "İslam Hukukunun Oluşumu ve Tarihsel Gelişimi”, 34.
} 
beraberinde getirmiştir. İçtihat metotlarını tespit etmek ve görüşlerin kendi içinde tutarlılığını korumak amacıyla fikhın dayandığı ilke ve kuralları tespit etme ihtiyacı fikıh usûlü ilmini meydana getirmiştir. Bu alanda İbn Lehîa, İmam Ebû Yusuf ve İmam Muhammed'in eser yazdığı nakledilmekle birlikte, geleneksel kabul bu ilmin kurucusunun İmam Şâfiî olduğu yönündedir. Bize ulaşan eseri er-Risâle'dir. ${ }^{102}$

\subsection{Bu Dönemde İhtilafi Etkileyen Unsurlar}

$\mathrm{Bu}$ dönemde hadislerdeki rivayet farklılıklarından kaynaklanan ihtilafları gidermek amacıyla, rivayetlerin Müslümanların tatbikatılla desteklenmesi gündeme gelmiştir. ${ }^{103} \mathrm{Bu}$ kapsamda İmam Malik'in Medine uygulaması (amelü ehli'l-Medine) ön plana çıkarken, Hanefîlerde meşhur sünnet vurgusu yapılmıştır. Evzâ̂̀nin "amel” kavramıla, önceki imamların uygulamalarına dikkat çekmesi de bu çerçevede değerlendirilmiştir. ${ }^{104}$ Hadislerin tedvini ve sahihinin zayıfından ayrılması fukahaya büyük kolaylık sağlamıştır. Bu durum hadise dayalı bazı ihtilafların ortadan kalkmasında etkili olmuş, fikhın gelişip olgunlaşmasına da zemin hazırlamıştir. ${ }^{105}$

Coğrafyanın görüşler üzerinde etkisi bulunmakla birlikte, bu dönemde her bölgenin fakihlerinin benzer görüşler etrafında buluştuğu ve görüşlerini ifade ederken genelde ilim öğrendikleri hocalarına nispet ettikleri görülmektedir. Örneğin Kûfe ekolünden bazı fakihler Ebû Yusuf un görüşlerine tabi olurken, bazıları İbn Ebî Leylâ'ya tabi olmuştur. Medine'de İmam Mâlik'in görüşleri Medine'nin icmâı olarak kabul edilmiştir. ${ }^{106}$ Aynı konuda birden fazla görüşün ortaya çıktı̆̆ı bu süreçte, özellikle re’y içtihadı kaynaklı görüşler arasındaki karışıklığı gidermek amacıyla icmâ kavramı gündeme gelmiş ve şâz görüşlere itibar edilmeyerek her bölgede yaygın olarak kabul gören görüş, o bölgenin icmâ1 olarak değerlendirilmiştir. ${ }^{107}$

\section{4. İlm-i Hilâfin Ortaya Çıkması}

İlk dönemlerde fukaha arasında oluşan ihtilaflar, fikıh kitaplarının ilgili bölümlerinde yer almıştır. ${ }^{108}$ Tedvin süreciyle birlikte her mezhep, görüşlerinin haklılığını dile getirme ve farklı görüş sahiplerine karşı savunma ihtiyacı hissetmiştir. Bu amaçla kaleme alınan ve günümüze kadar ulaşan ilk eser örnekleri arasında Evzaînin Siyeru'lEvzẩ, Ebû Yusufun, er-Redd alâ Siyeri'l-Evzẩ, İhtilâfu Ebî Hanîfe ve İbn Ebî Leylâ, Kitâbu'rRedd alâ Mâlik b. Enes; İmam Muhammed'in Kitâbu'l-Hucec fì İhtilâfi Ehli'l-Kûfe ve Ehli'lMedine ve İmam Şâfiînnin Kitâbu'r-Redd alâ Muhammed b. Hasen adlı eserleri gelmekte-

\footnotetext{
${ }^{102}$ George Makdısı, "Şâfiı̂’nin Hukukî Teoloji Anlayışı: Usûl-i Fıkhın Kökenleri ve Önemi”, çev. Sami Erdem, Marmara Üniversitesi İlahiyat Fakültesi Dergisi 13-14-15 (1997), 264.

103 Avc1, Flkhi İhtilafların Tarihsel Gelişimi,126.

104 Hassan, İslam Hukuk Ekollerinin Doğuşu, 50-51.

105 Hudarî, Târîhu't-Teşrî́il-İslâmî, 80-181; Köse, İslam Hukukuna Giriş, 161-162.

106 Hassan, İslam Hukuk Ekollerinin Doğuşu, 54-55.

107 Hassan, İslam Hukuk Ekollerinin Doğuşu, 49-50.

108 İzmirli İsmail Hakkı, İlm-i Hilâf, 3.
} 
dir. ${ }^{109} \mathrm{Bu}$ eserler, görüşlerin kendi içinde tutarlılığını ve güçlü yönlerini tespit etmede önemli veriler sağladıkları gibi, fikhın gelişmesine de katkıda bulunmuşlardır. Bu alandaki tartışmalar, fikıh usûlüne de zemin hazırlamıştır. Şâfiînin, er-Risâle isimli eserini kaleme almasından sonra, değişik mezheplerce eleştirilere cevap vermek ve mezhep içinde sistematik bütünlüğü korumak amacıyla, reddiye türü eserler yanında usûle ilişkin eserler yazılmıştır. ${ }^{110}$

\section{Mezhep ve Literatür Merkezli Gelişme Dönemi ve İhtilaf}

\subsection{Döneme Genel Bakış}

Bu dönem, hicrî dördüncü asrın ikinci yarısından Bağdat'ın Moğollar tarafından ele geçirilmesine kadar (656/1258) devam eden süreyi kapsamaktadır. Bu süreyi kanunlaştırma hareketleri ve yenilik arayışlarının yaşandı̆̆ı 19. yüzyılın ortalarına kadar devam ettiren hukuk tarihçileri de vardır. ${ }^{111}$

Siyasî olarak Bağdat Hulâgû tarafından 656/1258 yılında ele geçirilmiş, son Abbâsî halifesi Mu'tasım Billah ile birlikte binlerce insan katledilmiştir. Şehirler yağmalanmış, başta kütüphaneler olmak üzere mabetlere ve kültür değerlerine büyük zarar verilmiştir. Bununla birlikte Moğollar, bireysel dinî tercihler konusunda halkı özgür bırakmışlar ve fıkıh, teori ve pratik bazında yaşantısını devam ettirmiştir. Bunda fikhın siyasî otoriteden bağımsız olarak gelişmesinin etkili olduğu dile getirilmektedir. ${ }^{112}$

Bu döneme taklit damgasını vurmuştur. Bu yüzden "taklit dönemi” diye adlandıranlar da vardır. ${ }^{113}$ Zira kurucu içtihat faaliyetleri giderek azalmış, belli bir mezhebe ve önceki içtihatlara sıkı sıkıya bağlı kalma ön plana çıkmıştır. ${ }^{114}$ Bununla birlikte, fikhın kavram, teori ve usûl bağlamında olgunlaştığı, sistematik olarak gelenek halinde kökleștiği bir dönemdir. Bu yüzden "istikrar dönemi” veya "kurumsallaşma dönemi” diyenler de vardır. Bu devrede, şerh ve haşiyelerle fikıh geleneği yerini sağlamlaştırmıştır. ${ }^{115}$ Mezhep görüşleri, oluşan sistematik doğrultusunda delilleriyle birlikte düzenli olarak kitaplaşmıştır. Kaza ve fetvada hangi kaynakların kullanılacağı ve tercih sıralaması ortaya konmuştur. ${ }^{116}$ Mezhepler, kendi içinde tutarlı ve sistematik görüşler ortaya koymak suretiyle dinî görevlerini yerine getirmek isteyen bireylere güvenli bir yol sağlamayı hedeflemiştir. ${ }^{117} \mathrm{Bu}$ durumun belli

109 Özen, “ỉlm-i Hilâf Yahut Fukaha Metoduna Göre Cedel Hakkında Klasik Bir Metin: Menşeu'n-Nazar”, 171.

110 Avc1, Fıkhi İhtilafların Tarihsel Gelişimi, 127.

111 Muhsin Koçak vd., İslâm Hukuku (İstanbul: Ensar Neşriyat, 2020),106.

112 Köse, İslam Hukukuna Giriş, 164.

113 Vehbe Zühaylî, Usûlü'l-fikhi'l-İslâmî (Dımaşk: Dâru'l-Fikr, 1986), 2/1061, 1120.

114 Mehmet Erdoğan, Fı ıı İlmine Giriş (İstanbul: Dem, 2019), 58.

115 Yaman-Çalış, İslam Hukukuna Giriş, 125.

116 Koçak vd., İslâm Hukuku,106-107.

117 Hacı Mehmet Günay, “Günümüz Fıkıh Problemleri: Sebepler, Yöntemler ve Yaklaşımlar”, İslam Hukuku, ed. Talip Türcan (Ankara: Grafiker Yayınları, 2013), 625. 
usûl ve ilkelerden yoksun bazı yaklaşımların bertaraf edilmesinde ve mesnetsiz ihtilafların önlenmesinde etkili olduğunu söyleyebiliriz. Bu dönemi, fikhın gelişim seyri içinde "duraklama" ifadesiyle isimlendirenler olsa da sözü edilen kazanımların göz ardı edilmemesi gerektiği açıktır.

Bu dönemde fikıh çalışmaları mezhep yapılanması çerçevesinde sürdürülmüş ve oluşan gelenek dışında bağımsız içtihat muteber sayılmamıştır. Bu durumu içtihat kapısının kapanması şeklinde değerlendirenler de vardır. İbn Haldun, halkı belli bir mezhebe bağlı kalmaya sevk eden sebebi, yetersiz kişilerin içtihada yeltenmeleriyle izah etmektedir. ${ }^{118}$ Tedvin hareketiyle birlikte mezhep imamlarının görüşlerinin yaygınlaştığı, bu sebeple mutlak içtihada bir saha kalmadığı da dile getirilmektedir. ${ }^{119}$

Bunların yanı sıra, müçtehit imamların dirayetli duruşlarının, hüküm kaynakları ve yöntem bilgisinin artık yerleşmiş olmasının belirleyici olduğunu da ifade edilebiliriz. Yine hukuk güvenliği düşüncesi ve olumsuz etkenlere karşı fikhı koruma refleksinin göz ardı edilmemesi gerektiğini söyleyebiliriz. ${ }^{120}$

Şunu ifade edelim ki hicrî dördüncü asırdan itibaren içtihat kapısının kapandığı yönünde bir ön kabulden söz edilse de içtihat faaliyeti devam etmiştir. Ancak mutlak içtihadın yerini, mezhepte hükmü bulunmayan konularda mezhebin ilke ve usûlü çerçevesinde hükmü ortaya koyma şeklindeki mezhep içi fikhî istidlal (tahrîc) almıştir. $^{121}$

Bu dönemde ön plana çıkan bir husus da "hukukî istikrar" düşüncesidir. Farklı içtihatlar sebebiyle oluşan kargaşayı önlemek amacıyla bir müçtehidin görüşlerinin esas alınmasının gerekliliği güçlü şekilde dile getirilmiştir. İbnü'l-Mukaffa', Abbâsî halifelerine sunduğu teklifte hukukî istikrara duyulan ihtiyaca dikkat çekmiştir. ${ }^{122}$ Dördüncü hicrî asra gelindiğinde, artık hukuk güvenliği arayışları iyice kendini hissettirmiştir. Mezhep yapılanması bu ihtiyacı kısmen karşılamıştır. ${ }^{123}$

\section{2. İhtilafa Etkileri ve Sonuçları İtibarıyla Dönemin Değerlendirilmesi}

İhtilafa etkileri ve sonuçları bağlamında bu dönemin öne çıkan özelliklerini şöyle sıralayabiliriz:

1. Bu dönemde mutlak içtihat devri sona erdiğinden, her mezhebin mensupları kendi imamlarına bağlanmıştır.

\footnotetext{
118 Mezhep hükmüne bağlık kalınmasıyla ilgili değerlendirme ve geniş bilgi için bk. Ebû Abdilazîz Kutbüddîn Şah Veliyyullah Ahmed b. Abdirrahîm b. Vecîhiddîn Dehlevî, Ikdu'l-cîd fi ahkâmi'l-ictihâdi ve'ttaklîd (İstanbul: Hakikat Kitabevi, 1994), 37.

119 Karaman, İslam Hukukunda İctihad, 189.

120 Abdülazîm Şerefuddîn, Târîhu't-teşrî́i'-İslâmîve ahkâmu'l-müllkiyye ve'ş-şufa ve'l-akd (Bingazi:y.y., 1989), 205.

121 Tahrîc: Naklî, şer’̂̀ delillerin yanı sıra mezhep hükmünü de kaynak kabul eden fikhî bilgi elde etme sürecini ifade etmektedir. Bk. Tuncay Başoğlu, "Tahrîc”, Türkiye Diyanet Vakfi İslâm Ansiklopedisi (İstanbul: TDV Yayınları, 2010), 39/420. Kahraman, İslam Hukukuna Giriş, 253.

122 Bozkurt, Abbâsîler, 64.

123 Okur, "İslam Hukukunun Oluşumu ve Tarihsel Gelişimi”, 35.
} 
2. Mezheplerin yerleşmesi ve mutlak içtihat fikrinin zayıflamasıyla birlikte, artık mezhep imamlarından nakledilen görüşlerin illetlerini tespit etmek, dayanaklarını bulmak, fer'î meseleler üzerinde düşünmek ve yeni meseleleri de bu esaslar üzerinden çözüme kavuşturmak, dönemin karakteristik özelliği olarak ortaya çıkmıştır.

3. Mezhep imamlarının içtihat usûllerini tespit edebilmek amacıyla, verdikleri hükümler üzerinden istinbât kuralları belirlenmeye, böylece genel ilke ve esaslara ulaşılmaya çalışılmıştır. Birden fazla görüş bulunan hallerde bunlardan biri (müftâ bih) tercih edilmiștir.

4. Mezhep fikhını düzenleme ön plana çıkmıştır. Bu durum mezhebin temel metinlerini açıklamak (şerh), şerhte kapalı kalan kısımları anlaşılır kılmak (hâşiye) ve hâşiyede izah gereken ifadeleri açıklamak (ta'lîk) şeklinde gerçekleşmiştir. Ta'lîk'te kapalı kalan yerler de ta'lîku't-ta'lîk şeklinde açıklığa kavuşturulmuştur. Bu çalışmalar mezhebin anlaşılmasını ve yerleşmesini kolaylaştırmıştır. ${ }^{124}$ Bununla birlikte, söz konusu çalışmaların mevcudun tekrarı niteliği taşıdığı gözden uzak tutulmamalidir.

5. Mezhep imamına bağlılı̆̆ın ileri düzeyde olması, hatta mezhep görüşünün naslarla zahiren çelişmesi halinde mezhep görüşünün esas alınması gerektiği ifade edilmiştir. Hanefî fukahasından Kerhînnin dile getirdiği “Ashabımızın görüşlerine aykırı olan her âyet ya neshe ya da tercihe hamledilir. En uygunu te'vîl edilmesidir." ${ }^{125}$ sözü bu yaklaşımın çarpıcı örneklerinden biridir. ${ }^{126}$ Şâfiî fukahası içinde kendini ıslâhatçı konumda gören İbn Süreyc'in, "Şâfî̂'den nakledilen sahîh bir görüş bulunması halinde ona tâbi olmak, zâhiren buna aykırı olan görüşlere ise itibar etmeyip te'vîl etmek gerekir." ${ }^{127}$ şeklindeki sözleri de Kerhînnin yaklaşımıyla benzerlik taşımaktadır.

Mezhep taassubunda bulunduğu ve taklit ruhunu beslediği gerekçesiyle eleştirilen bu yaklaşım, dönemin karakteristik özelliği olan mezhebe sıkı bağl1lı̆̆ın bir yansıması olarak değerlendirilebilir. Şu da bir gerçektir ki, dönemin önde gelen fakihlerinin dile getirdiği bu görüşler, mezhep içi istikrarı sağlamada ve mezhep görüşlerinin sistemleşerek güçlü bir ekol haline gelmesinde oldukça etkili olmuştur.

6. Mutlak içtihat faaliyetinin zayıflaması sebebiyle, mezhep imamlarının görüşlerini açıklama, savunma ve üstünlüklerini dile getirme gayretleri öne çıkmıştır.

124 Hudarî, Târîhu't-teşrîili-islâmî, 346-350.

125 Ebu'l-Ferec Muhammed b. Ebî Ya'kûb en-Nedîm, el-Fihrist (Beyrut: Dâru'l-Ma'rife, ts.), 261.

${ }^{126}$ Kerhînin er-Risâle isimli eserinde dile getirdiği bu görüşle kastedilen, büyük bir olasılıkla mezhep hükmü ile çatışan bir nassın, mezhep imamlarınca mutlaka görülmüş ve incelenmiş olduğu, dolayısıyla nas ile hüküm verilmemesinin usûle dayalı (metodik) bir yaklaşımdan kaynaklandığıdır. Bu itibarla, söz konusu ifadeyi mezhep görüşüyle çelişen nassa yönelik ilkesel bir yaklaşım olarak değil, hükmü ortaya koyarken, fiilen tamamlanmış bir sürecin arka planını ve nasıl anlaşılması gerektiğini açıklama bağlaminda değerlendirmek daha isabetli gözükmektedir. Bk. Ubeydullah b. el-Hüseyin b. Dellâl Kerhî, erRisâle (İstanbul: Eda Neşriyat, 1990), 169; Yaman-Çalış, İslâm Hukukuna Giriş,128.

127 Tâcuddîn Abdülvehhâb b. Ali es-Sübkî, Tabakâtu'ş-şâfi iyyeti'l-kübrâ (Kâhire: Dâru İhyâi'l- Kübi'l-Arabî, 1918), 3/21-28. 
Mezhep görüşlerini savunmak ve eleştirilere cevap vermek amacıyla yapılan cedel ve münazaralar zengin bir fikhî birikim oluşmasına, fikhın kurumsal yapısının güçlenmesine ve köklü bir fikıh geleneğinin teşekkülüne katkı sağlamıştır. ${ }^{128}$ Yöntem belirleyen bu gelenek, sonraki dönemlerde ortaya çıkan meselelere çözüm arayışlarında yön verici değerli bir kaynak olmuştur. Bunun sonraki dönemlerde oluşabilecek ihtilafların azalmasında da etkili olduğunu söyleyebiliriz.

7. Taklit anlayışı, mezheplerarası ihtilafları belirgin hale getirmiştir. Her mezhep kendi düşüncesinin üstün olduğunu ve hükümlerinin isabetli olduğunu ortaya koymak üzere eserler vücuda getirmiştir. İlm-i hilâf adıyla ortaya çıkan bu özel alanda pek çok eser kaleme alınmıştır. ${ }^{129}$ Bu konuda ilk olarak Tahâvînnin (öl. 321/933) İhtilâfu'l-fukahầ'sıla, Taberînnin (öl. 428/1036-1037) yine aynı adla yazdı̆̆ı eseri ön plana çıkmaktadır. Sonraki dönemlerde bu alana ilişkin zengin bir literatür ortaya çıkmıştır. ${ }^{130}$ Hilâf ilminin kaidelerini temellendirmesi ve literatüre getirdiği yeni sistem dolayısıyla Karahanlılar döneminde yaşayan Ebû Zeyd ed-Debusî (öl. 430/1039) bu ilmin kurucusu olarak kabul edilmektedir. ${ }^{131}$

Ortaya çıkan yeni meselelerle ilgi çözüm önerilerini ihtiva eden fetâvâ, nevâzil ve vâkıât adıyla yazılan eserler bu dönemin bir başka özelliğidir.

8. Bu dönemin dikkat çeken bir başka yönü, örfî hukuk ve kanunname geleneğidir. Özellikle Osmanlı hukuk sisteminde, fikıh doktrinine dayalı şerî hukuk yanında hükümdarın iradesine bağlı olarak hukuk kuralı niteliği kazanan örfî hukuk ve kanunnâmeler ortaya çıkmıştır. Örfî hukuk çerçevesinde ortaya konan kanunnameler içinde Fatih, II. Bayezit, Yavuz ve Kanunî dönemlerinde düzenlenen kanunnameler

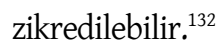

\section{Günümüzde İslam Hukuku ve İhtilaf}

Sanayi devriminin gerçekleștiği 18. yüzyıl, birçok açıdan olduğu kadar İslam hukukuna etkileri açısından da dönüm noktası olmuştur. Bu süreçte teknoloji, her geçen gün yeni gelişmelere sahne olmuş, buna bağlı olarak iletişim dünyası hızlı bir değişim ve dönüşüm yaşamıştır. Yakın zamanda bu alandaki gelişmelerin hızı ve kapsamı geçmişle mukayese edilemeyecek derecede artmıştır. Ticaret hayatındaki ivme; yeni ticaret yöntemleri, dijital para, sanal ortamda alım-satım ve pazarlama işlemleri, enflasyon, faiz, işçi-işveren ilişkileri, sigorta gibi konuları beraberinde getirmiştir. Tıp alanında DNA testleri, kök hücre, taşıyıcı annelik ve insan kopyalanması konuları gündeme gelmiştir. Teknolojik gelişmelerin başta ceza, borçlar ve ticaret hukuku olmak üzere, hukukun farklı alanlardaki etkileri kendini güçlü şekil-

\footnotetext{
${ }^{128}$ Ferhat Koca, "Hilâf (Mukayeseli İslam Hukuku) i̇lminin Mahiyeti, Doğuşu, Gelişmesi ve Literatürü”, Mukayeseli İslam Hukuk Düşüncesinin Temellendirilmesi (Ankara: Ankara Okulu Yayınları, 2018),166.

${ }^{129}$ Muhammed b. Cerîr et-Taberî, îhtilâfu'l-fukahâ (Beyrut: Dâru'l-Kütübi'l-ilmiyye, ts.), 247.

${ }^{130}$ Bu konuda geniş literatür bilgisi için bk. Ebû Abdillah Muhammed b. Nasr Mervezî, İhtilâfu'l-fukahâ (Riyad: Dâru Advâi's-Selef, 2000), 54-60.

${ }^{131}$ İzmirli, İlm-i Hilâf, 4.

${ }^{132}$ Mehmet Akman, "Örf”, Türkiye Diyanet Vakfi isslâm Ansiklopedisi (istanbul: TDV Yayınları, 2007). 34/93-94.
} 
de hissettirmiştir. Tarım alanında GDO'lu ürünler, gıda ürünlerinde kullanılan ve insan sağlığını tehdit eden katkı maddeleri ve bunlara yönelik ortaya çıkan sorunlar, çok kapsamlı gelişimin sadece birkaç örneğidir. Yine kadının sosyal hayattaki rollerine ilişkin farklı bakış açıları; çevrenin korunmasına ilişkin yeni tedbirler ve anlayışlar, çevre bilincinin gelişmesiyle birlikte daha da önem kazanan çevre sorunları; hızlı teknolojik gelişime bağlı olarak artık daha çok konuşulan "uzay hukuku" çalışmaları da bugün tanık olduğumuz gelişimin sınırlı sayıdaki diğer örnekleri olarak zikredilebilir. Bugün bütün dünyayı sarsan covid-19 adlı virüsün sağlık, ticaret ve sosyal alandaki etkileri kadar, dinî hayat üzerindeki tesiri de en sıcak ve yıkıcı gündem konusudur. Bütün bu gelişmelerin İslam fikhını çok yönlü etkilediği, farklı yöneliş ve kanaatleri ortaya çıkardığı ve ihtilaf olgusunu derinleştirdiği izahtan vârestedir. Elbette benzer sorunlar tarihsel süreçte de yaşanmıştır. Ancak mevcut durum eskiye göre daha grift ve karmaşıktır. Bilgiye ulaşımın kolaylaştığı, küresel ölçekte ve zengin mecralarda paylaşıldığı günümüzde, fikhî bilginin sıhhati ve yanlış paylaşımların verdiği zarar ise ayrı bir araştırma konudur.

Bugün, İslam hukukunun kısmen işaret ettiğimiz çağdaş problemlere çözüm üretmede yeterince etkili olamadığı, modern düşünce ile zaman zaman çatıştığı ve kendisini yenileyecek mekanizmaları istenilen düzeyde geliştiremediği yönünde iddialar ye almaktadır. Bu meyanda, mevcut fikıh usulünün yeterli olmadığı, fikıh ve usûl hakkındaki müktesebatımızla ve bakış açılarımızla yüzleşmemiz gerektiğini ifade eden söylemler dile getirilmiştir. ${ }^{133}$ Özellikle son iki asırdan bu yana çok tartış1lan ve araştırma konumuz olan ihtilafı da doğrudan etkileyen bu meselelerin çözümü bağlamında bireysel ve kolektif çabaların varlığı bilinen bir husustur. Bu noktada yaklaşı 7. yüzyıldan itibaren çekingen bir şekilde de olsa, yeniden mutlak içtihada duyulan ihtiyaç konusunda bir söylem oluşmaya başlamıştır. İbn Teymiyye, İzzuddîn b. Abdusselam, İbn Kayyım el-Cevziyye gibi âlimler bu söylemin başta gelen mimarları arasındadır. İbn Teymiyye, ıslah projelerinin hemen hepsinin referans noktası olmuştur. Bu düşüncedeki bilginlerce, naslara ve temel amaçlara uygun olan bir çözümün başka bir mezhepte bulunması halinde bu görüşlerden de istifade edilmesi gerektiği ifade edilmiştir. ${ }^{134}$

İslam'ın, özü itibarıyla modern dünyanın ihtiyaçlarına cevap verebilecek potansiyele sahip olduğunu, yaşanan problemlerin temelinde içtihat kapısının kapatılması ve taklidin yaygınlaşması olduğunu ileri sürerek, güçlü bir şekilde içtihat çağrısı yapanlar da vardır. ${ }^{135}$ Buna mukabil, bahsedilen içtihat vurgusunu aşırı bulan

${ }^{133} \mathrm{Bu}$ konularda kapsamlı görüş ve değerlendirmeler için bk. İbn Teymiyye vd., İctihad, Taklîd ve Telfik Üzerine Dört Risâle, haz. Hayreddin Karaman (İstanbul: Dergâh Yayınları, 1982), 25-283; Ali Bardakoğlu, İslâm Işığında Müslümanlığımızla Yüzleşme, (İstanbul: Kuramer, 2016), 225-356; Kemal Gözler, Fıkıh-Hukuk İlişkisi Üzerine, (Bursa: Ekin Basın Yayın Dağıtım, 2019), 63-71.

${ }^{134}$ H. Yunus Apaydın, “İçtihat: Dinin Hayatla Buluşması”, İslam'a Giriş Ana Konulara Yeni Yaklaşımlar, ed. Bünyamin Erul (İstanbul: Diyanet İşleri Başkanlığı Yayınları, 2008) , 99.

${ }^{135}$ Hayreddin Karaman, "Fıkıh Mezhepleri”, İctihad, Taklîd ve Telfik Üzerine Dört Risâle, İbn Teymiyye vd. (İstanbul: Dergâh Yayınları, 1982), 28. 
ve geleneksel anlayışlarla yeni yönelişlerin arasını birleştirmeye çalışan bir eğilim de söz konusudur. Bu eğilim, geleneksel içtihatlar içinden uygun olanları seçme ve yeni karşılaşılan problemleri "kolektif içtihat” yoluyla çözüme kavuşturma çabasındadır. ${ }^{136}$

Esasen problem, yalnızca içtihadın yapısıyla ilgili değildir. Naslarla olgu, dinle hukuk arasındaki irtibat, klasik fikıh müktesebatını anlamada yöntem, toplum yararı, hukukun teşekkülünde dinin katkı biçimi, birey ve beșerî iradenin rolü gibi birçok konuda, kavramsal çerçeve ve metodolojinin yeterince olgunlaşmamış olması, yine içtihatın bu konulardaki güçlü ve vazgeçilmez katkısının yeterince dikkate alınmamasıyla yakından ilgili görünmektedir. ${ }^{137}$

İslam hukuku, günümüzde dünya genelinde sayıları iki milyara yaklaşan Müslüman toplumlarda hayatı düzenlemedeki etkisini sürdürmektedir. Bu alanda yapılan çalışmaların bir kısmı kanunlaştırma düzeyinde bir kısmı da başta üniversiteler olmak üzere resmî ve sivil alanda akademik düzeyde sürmektedir. İslam dünyasında modernizmle başlayan ıslah ve tecdit çalışmaları, farklı mezheplerin görüş ve kanaatlerinden de istifade edilmesi bağlamında yeni bir duyarlılık oluşturmuştur. Geçmişin değerli mirasının bütünüyle kucaklanması gereğine inanılan bu anlayışta, bugünün sorunlarına çözüm olabilecek farklı görüş ve kanaatlerin uygun olanlarından istifade edilmesi yoluna da gidilmiştir. ${ }^{138}$

Tarihsel süreçte fikhî meselelere çözüm bulmak, gereksiz ihtilaf ve çekişmeleri gidermek amacıyla bireysel çabalar yanında kurumsal çalışmalar da yer almıştır. Bu kapsamda Osmanlı döneminde Şeyhulislamlık makamına bağlı olarak hizmet veren Fetvâhâne, sorulara cevaplar vermiştir. ${ }^{139}$ Ebussuûd Efendi ve Ali Efendi'nin fetvaları, Fetâvâyı ankaravî ve el-Fetâva'l-hayriyye gibi fetva kitapları yayımlanmıştır. İslam ülkelerinde belli kuruluşlar fikhî meselelerin çözümünde görev üstlenmişlerdir. Bunlar arasında yer alan ve Mısır'da Ezher üniversitesine bağlı olarak 1961 yılında kurulan Mecmau'l-Buhûsi'l-İslâmiyye; 1981 yılında Suudi Arabistan'da İslam Konferansı Teşkilatı'na bağlı olarak kurulan Mecmau'l-Fıkhi'l-İslâmî; Mekke'de 1976 yılında kurulan Râbitatü'l-Âlemi'l-İslâmî başta olmak üzere, Amerika Birleşik Devletleri, Avustralya, Avrupa, Cezayir, Pakistan, Hindistan ve Malezya gibi ülkelerde çeşitli kurum ve kuruluşlar bulunmaktadır. ${ }^{140}$ Türkiye'de Diyanet İşleri Başkanlığı bünyesindeki Din İşleri Yüksek Kurulu Başkanlığı da bu kapsamda etkin olarak hizmet veren kuruluşlar arasındadır.

Söz konusu kurullarda, genel prensip olarak alan uzmanlarından istifade edilmekte, özellikle tıp, iktisat, bankacılık gibi özel bilgi gerektiren konularda saha uzman-

\footnotetext{
136 Apaydın, “İslam'a Giriş Ana Konulara Yeni Yaklaşımlar”, 100.

137 Apaydın, "İslam'a Giriş Ana Konulara Yeni Yaklaşımlar”, 100.

138 Ahmet Ünsal, "Mukayeseli Fıkıh Çalışmaları", Fıkıh, ed. İbrahim Çalışkan (Ankara: Ankara Üniversitesi Basımevi, 2009), 215.

139 Ferhat Koca, "Fetvahâne”, Türkiye Diyanet Vakfi İslâm Ansiklopedisi (İstanbul: TDV Yayınları, 1995), 12/496500.

140 Bu konuda ayrıntılı bilgi için bk. Yaman-Çalış, İslam Hukukuna Giriş,131-132.
} 
larının görüşlerine başvurulmakta, çağdaş fikhî konularda bilimsel toplantılar düzenlemekte ve sonuçlar kamuoyu ile paylaşılmaktadır. İstişârî nitelikli bu tür kararların, bireysel fetvalara nispetle toplum üzerinde daha etkili olduğunu ve güven verdiğini söyleyebiliriz. Yine ortak akılla çalışan bu tür kuruluşların, şâz denilebilecek bazı görüşlerle faydasız tartışma ve ihtilafların giderilmesinde olumlu katkılar sağladığı ifade edilebilir.

Fetva merkezli çalışan söz konusu kurulların yanı sıra, üniversiteler bünyesinde yapılan bilimsel çalışmaların da günümüz fıkıh problemlerinin çözümüne $1 s ̧ ı k$ tuttuğu, hukukî temelden yoksun ihtilafların ortadan kaldırılmasına yardımcı olduğu ve sağduyulu yaklaşımların gelişmesine katkı sağladığını söyleyebiliriz.

\section{Sonuç}

İnsanın doğuştan sahip olduğu kişisel özellikleri fitratın bir gereğidir ve doğal ihtilaf sebebidir. Tarih boyunca insanın olduğu her yerde ihtilaf olmuştur. İhtilafın tarihi, insanın tarihi serüveni kadar eskidir. Fıkhî ihtilafların tarihsel süreci de fikhın tarihi ve gelişim süreciyle yakından ilgilidir. Bu itibarla sebepleri, sonuçları ve İslam hukukuna yansımaları bağlamında bir "ihtilaf fikhı"ndan söz edebiliriz.

İslam âlimleri ilk dönemlerden itibaren kesin bilgi ile sabit olan yoruma kapalı itikadî, amelî konularda ve dinin temel sabitelerinde ihtilaf etmemişlerdir. İslam toplumunda güven ve huzuru, birlik ve beraberliği zedeleyen, kin ve düşmanlığa götüren ihtilaflar kabul görmemiştir. Ancak içtihada açık alanlarda doğruyu bulma amaçlı çabalar sonucu oluşan fikhî ihtilaflar tarih boyunca var olmuş ve ilkesel olarak doğal karşılanmıştır. Sahâbe, tâbiîn ve müçtehit imamlar pek çok fikhî konuda ihtilaf etmişlerdir.

Hz. Peygamber döneminde ashap arasında yaşanan ihtilafları çözmede son merci Allah'ın elçisidir. O'nun sahabe arasındaki ihtilaflı konularda verdiği kararlar, Hz. Peygamberin hükmü olarak yansımıştır. Hz. Peygamberin sağlığında ashap arasında yaşanan ihtilaflar, içtihada dayalı konularda farklı görüşlerin bulunabileceğine delil olarak gösterilmiştir.

Sahâbe döneminde ihtilaf azdır. Özellikle Hz. Ebû Bekir ve Hz. Ömer döneminde uygulanan şûrâ temelli kararlar, Medine'de hadis malzemesinin çok olması, önde gelen sahâbe etrafında oluşan ilim meclisleri ve onların kararlarına tabi olma konusunda duyarlı geniş kitleler, ihtilafın az olmasının başlıca sebepleri arasında zikredilebilir. Sahâbenin fetva vermede temkinli davranması ve olabildiğince hüküm vermemeyi tercih etmesi de ihtilafi azaltan bir unsur olmuştur.

Hz. Ebû Bekir ve Hz. Ömer döneminde ashâb, yeni ortaya çıkan meselelerin çözümünü istişare yoluyla gerçekleştirmişlerdir. Bu dönemde bireysel içtihatlar yerini şûrâya bırakmıştır. Şûrâ yöntemiyle alınan kararlar ihtilafların azalmasında etkili olduğu gibi, sonraki dönemlerde hüküm istinbâtında dikkate alınan bir delil vasfi kazanmıştır. Hz. Peygamberin vefatından sonra farklı coğrafyalara yerleşen sahâbe, Hz. Peygamber döneminin canlı tanıkları ve dönemin ilmî mirasının taşıyıcıları olarak, 
görüş ve kanaatleriyle bulundukları yerlerde bir çekim merkezi ve dinî problemleri çözmede birer başvuru mercii olmuşlardır. Sahâbenin bu süreçte ortaya koyduğu re'y ve kanaatler, sonraki neslin fikıh anlayışının şekillenmesinde büyük ölçüde etkili olmuştur.

Tâbiîn dönemi, içtihat faaliyetlerinin ivme kazanarak devam ettiği bir süreçtir. Sahâbenin hüküm istinbâtında başvurduğu yöntemlere ve bıraktı̆̆ı fikhî kazanımlara sahip olan tâbiîn fukahası, genişleyen İslam coğrafyası, artan fikhî problemler ve yoğun içtihat faaliyetiyle daha zengin bir fikıh mirasına sahip olmuştur. Tâbiîn dönemi, dinamik fikhî yapısıyla İslam hukukunun teşekkülünde etkin bir süreci temsil etmektedir. Sahâbe döneminden farklı olarak, bu dönemde farazî meseleler üzerinde de görüş serdedilmiştir. Hicrî dördüncü asırdan itibaren artık her içtihadî meselenin bir karşlığı ve çözümü olduğu ve yeni bir içtihada gerek kalmadığı şeklindeki kanaat gittikçe yerleşmiştir. Bu durum içtihat kapısının kapandığı yönündeki kanaati de güçlendirmiştir. Tâbiîn döneminde yaşanan ihtilaflar, çoğunlukla mekân ve bölgeye dayalı ithilâflardır. Sözün hakikat veya mecaz anlamında kullanılması, hadisin bilinip bilinmemesi, hadisin sıhhati, içtihat usûlünün farklılığı ve sosyal çevre gibi etkenler de başlıca ihtilaf sebepleri arasında yer almıştır.

Müçtehit imamlar dönemi, içtihat faaliyetinin yoğun olduğu, fikhın en canlı olduğu "altın çă̆"dır. Bu dönemde hadislerin tedvin süreci tamamlanmış, sahâbe ve tâbiînin görüşleri ilim merkezlerinde yaygın hale gelmiştir. Fıkıh malzemesinin artması, ihtilafların çoğalmasını da beraberinde getirmiştir. Fukaha, ihtilafları ortadan kaldırmak amacıyla farklı görüşler arasında tercihte bulunmuş, şâz olan görüşleri değerlendirme dışı bırakmışlardır. Bu durum, her bölgede yaygın olan içtihatların öne çıkmasına, bir nevi bölgesel icmâ oluşmasına neden olmuştur. Bölgesel kararlar, bireysel kanaatleri de etkilemiştir. Müçtehit imamlar dönemi, mutlak içtihatın öne çıkması ve usûl kurallarının ortaya konulmasıyla da temayüz etmiştir. Fikirler olgunlaşmış, liyakat sahibi âlimler fikhî kanaatlerini özgürce ortaya koymuşlardır. Yine re'y içtihadı sistemleşmiş ve temel eğilimler etrafında bir ekolleşme yaşanmıştır. Söz konusu ekoller içinden "mezhep" adıyla şahıs merkezli yeni bir hukukî yapılanma ortaya çıkmıştır. Sahâbe döneminde ağırlıklı olarak hoca ve çevre farkına dayanan ihtilaflar, Abbasiler ile birlikte daha çok prensip ihtilafına dönüşmüştür.

Taklit döneminde, mutlak içtihat yerini belli bir mezhebe bağlanmaya bırakmış ve meselelerin mezhep içi kurallar çerçevesinde çözüme kavuşturma gayretleri yoğunluk kazanmıştır. Mezhep hükümlerini yazan, bu doğrultuda fetva veren ve uygulayan güçlü talebeler, mezheplerinin güçlenmesine katkı sağlamıştır. Bu durum taklidin yerleşmesine de zemin oluşturmuştur.

Sahâbe ve tâbiîn ile sonraki dönemde gelen İslam hukukçuları, karşılaştıkları meselelerde temel bir yaklaşım olarak öncelikle Kur'an ve Sünnet'e başvurmuşlardır. İslam'ın ana kaynaklarıyla ters düşmediği, İslam hukukunun genel ilke ve kurallarıyla çelişmediği sürece, zaman ve coğrafyanın tabii şartları içinde oluşan ve liya- 
kat sahibi fakihler nezdinde vuku bulan ihtilaflar, müslümanlar için genişlik ve kolaylık olarak görülmüştür. Ömer b. Abdülaziz'in şöyle söylediği rivayet edilmiştir: "Eğer Allah Resulünün ashabı ihtilaf etmeselerdi üzülürdüm. Çünkü bir kişinin sözü insanlar için darlık ve sıkıntı getirir. Onlar kendilerine tabi olunan imamlardır. Onlardan herhangi birinin görüşünü almakla kişi için genişlik vardir."

İçtihada açık konularda bütün müçtehitlerin aynı kanaate sahip olmasını veya bir görüşe herkesin tabi olmasını beklemek, ihtilafı ortadan kaldırmak gibi temelde iyi niyete dayalı bir düşünce olsa da bunun dinî, hukukî ve rasyonel zemini olmadığını ifade etmeliyiz.

Mezhepler arası ihtilaflar, genellikle müçtehitlerin benimsediği ilke ve usullerle ilgilidir. Müçtehidin bulunduğu yerdeki yaşantı biçiminden, örf-adet ve maslahat gibi birçok hukukî gerekçe ile yakından ilgilidir. Bütün müçtehitlerin gayesi, içtihada konu olan meselede "murâd-1 ilâhi"ye ulaşmaktır. Bu yüzden içtihat ehliyetine sahip fakihlerce, usûlüne uygun şekilde yapılan her içtihat değerlidir ve başka bir içtihatla nakzedilemez. Müçtehit, hata etse de ma'zurdur ve ecir alır. Müçtehidi kararlarında özgür kılan, hatta bir nevi koruma altına alan şer'î müjdeyi, zımnen belli ihtilafların her zaman bulunabileceğine ilişkin bir işaret olarak da değerlendirmek mümkündür.

İhtilafı tamamen ortadan kaldırmaya çalışmak ve ihtilafsız bir dünya tasavvur etmek, yeni ihtilaflara kapı aralayacaktır. Aslolan ihtilaf gerçeğini kabul etmek, hukukî niteliğini kavramak ve farklı bir ufuk olarak değerlendirebilmektir. İhtilafı, iftiraka ve fitneye dönüştürmemektir. Hatta bir "İhtilaf ahlakı" geliştirebilmektir.

Kur'an ve Sünnet'e aykırı olmadı̆̆ı, icmâ ve hukukun temel ilkeleriyle ters düşmediği sürece, fürû-1 fikıhta oluşan ihtilaflar genişlik ve kolaylıktır. Zaruri durumlarda çıkış yoludur. Hukukî problemleri çözmede değerli bir tecrübedir. İslam hukukunda evrenselliğin ve sürekliliğin sağlanmasında önemli vasıtalardan biridir. Bu yönüyle ihtilaf, rahmet kabul edilmiştir. "Doktrindeki ihtilafi anlamayan kişi, fikhın gerçek kokusunu alamaz" ifadesi bu gerçeğin başka bir yansımasıdir.

Etik Beyan / Ethical Statement

Yazar / Author
$\mathrm{Bu}$ çalışmanın hazırlanma sürecinde bilimsel ve etik ilkelere uyulduğu ve yararlanılan tüm çalışmaların kaynakçada belirtildiği beyan olunur/It is declared that scientific and ethical principles have been followed while carrying out and writing this study and that all the sources used have been properly cited.

Yüksel Salman

141 Beyânûnî, Dirâsât, 16. 


\section{Kaynakça}

Akman, Mehmet. "Örf”. Türkiye Diyanet Vakfi İslâm Ansiklopedisi. 34/93-94. İstanbul: TDV Yayınları, 2007.

Alevânî, Tâhâ Câbir. Edebü'l-ihtilâf fi'l-İslâm. Amerika Birleşik Devletleri: Silsiletü Kadâyâ elFikri'l-i̇slâmî, 2. Basım, 1987.

Ali el-Hafif. Esbâbu ihtilâfi'-fukahâ. Kahire: Dâru'l-Fikri'l-Arabî, ts.

Ali Hasan, Abdulkâdir. Nazratu'n-âmme fi târîhi'l-fikhi'l-islâmî. Misır: Mektebetü'l-Kahire,1956.

Apaydın, H. Yunus. İslam Hukuk Usûlü. Ankara: BİLAY, 5. Basım, 2018.

Apaydın, H. Yunus. "Re'y". Türkiye Diyanet Vakfi İslâm Ansiklopedisi. 35/37-40. İstanbul: TDV Yayınları, 2008

Apaydın, H. Yunus. “iç̧tihat: Dinin Hayatla Buluşması”, İslam'a Giriş Ana Konulara Yeni Yaklaşımlar. ed. Bünyamin Erul. 81-101. İstanbul: Diyanet İşleri Başkanlığı Yayınları, 4. Basım, 2008.

Avcı, Aykut. "Fikhi İhtilafların Tarihsel Gelişimi”. Bozok Üniversitesi İlahiyat Fakültesi Dergisi 8/8 (2015/8), 119-132.

Avvâme, Muhammed. Edebü'l ihtilâffîmesâili'l-ilmi ve'ddîn. Beyrut: Dâru'l-Beşâir el-İslâmiyye, 1997.

Avvâme, Muhammed. Eserü'l-hadîsi'ş-șerîf fì ihtilâfil-eimmeti'l-fukaha. Beyrut: Dâru'l-Beşâir elİslâmiyye, 4. Basım, 1997.

Aynî, Mehmed Fıkhî. Risâle fi edebi'l-müftî. thk. Osman Şahin. İstanbul: TDV İslam Araştırma Merkezi, 1. Basım, 1439/2018.

Bardakoğlu, Ali. İslâm Işığında Müslümanlığımızla Yüzleşme. İstanbul: Kuramer, 1. Basım, 2016.

Başoğlu, Tuncay. "Tahrîc”. Türkiye Diyanet Vakfi İslâm Ansiklopedisi. 39/420-422. İstanbul: TDV Yayınları, 2010.

Beyânûnî, Muhammed. Dirâsât fi'l-ihtilâfâti'l-ilmiyye. Kahire: Dâru's-Selâm, 4. Basım, 2013.

Beyânûnî, Muhammed. Fıkhu'l-i'tilâf ve'l-ihtilâf. Riyad: Kürsiyyü'l-Emîr Sultan b. Abdilazîz li'ddirâsâti'l-i̇slâmiyye el-Muâsıra, 1431.

Bilmen, Ömer Nasuhi. Hukukı İslâmiyye ve Istılahatı Fikhiyye Kamusu. İstanbul: Bilmen Yayınevi, 1985.

Bozkurt, Nahide. Abbâsîler (750-1258). Ankara: Türkiye Diyanet Vakfı Yayınları, 5. Basım, 2018.

Buhârî, Muhammed b. İsmail. el-Câmi'u's-sahîh. 8 Cilt. İstanbul: Çağrı Yayınları, 2. Basım, 1992.

Cessâs, Ebû Bekir Ahmed b. Ali er-Râzî. Ahkâmu'l-Kur'an. 5 Cilt. Beyrut: Dâru İhyâi't-Türâsi'lArabî, 1405/1985.

Coulson, Noel J. İslam Hukuk Biliminde İhtilaf ve Gerilimler. çev. Ferhat Koca. Ankara: Ankara Okulu Yayınları, 2016.

Cürcânî, Ali b. Muhammed b. es-Seyyid Şerîf. et-Ta'rîfât, b.y.: y.y., ts.

Çalışkan, İbrahim. "Fıkıh Mezheplerinin Oluşum Süreci ve Fakihler Arasındaki Fıkhi İhtilafların Sebepleri”. Fıkı. ed. İbrahim Çalışkan. 39-61. Ankara: Ankara Üniversitesi Basımevi, 4. Basım, 2009.

Debûsî, Ebû Zeyd. Te'sîsün-nazar, thk. ve tsh. Mustafa Muhammed Kabbânî. İstanbul: Eda Neşriyat, 1990.

Dehlevî, Şah Veliyyullah. Huccetullâhi'l-bâliğa. Beyrut: Dâru'l-Kütübi'l-İlmiyye, 1995.

Dehlevî, Şah Veliyyullah. Kitâbu'-İnsâf. İstanbul: Hakikat Kitabevi, 1994.

Dehlevî, Şah Veliyyullah. Ikdu'l-cîd fî ahkâmi'l-ictihâdi ve't-taklîd. İstanbul: Hakikat Kitabevi, 1994. 
Demir, Halis. "Hanefi Mezhebinde Hilâf Literatürü”. Cumhuriyet Üniversitesi İlahiyat Fakültesi Dergisi 19/2 (Aralı 2015), 111-146.

Döndüren, Hamdi. "Sosyal Değişme Karşısında İslam Hukuku ve Yeni Yaklaşımlar". İslam Hukuku Araştırmaları Dergisi 1 (2003), 29-50.

Ebû Dâvûd, Hâfiz Süleyman b. Eş'as es-Sicistânî. es-Sünen. 5 Cilt. İstanbul: Çağrı Yayınları, 2. Basım, 1992.

Ebû Yûsuf, Yakûb b. İbrahim. Kitâbu'l-Harâc. Mısır: y.y., 1352.

Ebû Zehra, Muhammed. Târîhu'l-mezâhibil-İslâmiyye fi's-siyâse ve'l-akâid ve târîhi'l-mezâhibilfikhiyye. Kahire: Dâru'l-Fikri'l-Arabî, ts.

Ebû Zehra, Muhammed. Muhâdarât fî Usûli'l-Ca'ferî. Mısır: y.y.,1956.

Efendioğlu, Mehmet. "Sahâbe". Türkiye Diyanet Vakfi İslâm Ansiklopedisi. 35/491-500. İstanbul: TDV Yayınları, 2008.

Ekinci, Ekrem Buğra. İslâm Hukuku Tarihi. İstanbul: İstanbul Arı Sanat Yayınları, 2006.

Ensârî, Ahmed b. Muhammed. Âsâru ihtilâfi'l-fukahâ fi'ş-şerĩa. Riyad: Mektebetü Rüşd, 1996.

Erdoğan, Mehmet. Fikı İlmine Giriş. İstanbul: Dem, 2019.

Gözler, Kemal. Fıkıh-Hukuk İlişkisi Üzerine. Bursa: Ekin Basın Yayın Dağıtım, 1. Basım, 2019.

Günay, Hacı Mehmet. “Günümüz Fıkıh Problemleri: Sebepler, Yöntemler ve Yaklaşımlar”.

İslamHukuku. ed. Talip Türcan. 615-631. Ankara: Grafiker Yayınları, 2013.

Haçkalı, Abdurrahman. "Ehl-i Hadis-Ehl-i Re'y Ayrışması Fıkhî mi, İtikâdî mi?”, İslam Hukuku Araştırmaları Dergisi 2 (2003), 59-68.

Hallâf, Abdülvehhâb. İlm-i usûli'l-fikh. İstanbul: el-Mektebetü'l-İslâmiyye, 7. Basım, 1984.

Hallâf, Abdülvehhâb. Hulâsatu't-teşrî́il-İslâmî. Kahire: Matbaatu'n-Nasr, 7. Basım, 1956.

Hassan, Ahmed. İslam Hukuk Ekollerinin Doğuşu, çev. Ali Hakan Çavuşoğlu-Hüseyin Esen. İstanbul: İz Yayıncıllk, 1999.

Hudarî, Muhammed. Târîhu't-teşrî́il-İslâmî. Beyrut: Dâru İhyâi't-Türâsi'l-Arabî,7. Basım,1960.

Isfahânî, Ebu'l-Kâsım Hüseyin b. Muhammed Râgıb. el-Müfredât fi garîbi'l-Kur'ân. thk. Mustafa el-Bâz. Mekke: Mektebetü Nezzâr Mustafa el-Bâz, 2009.

İbn Âbidîn, Muhammed Emîn. Reddü'l-muhtâr ale'd-dürri'l-muhtâr şerhu tenvîri'l-ebsâr. 6 Cilt. b.y.: Matbai Âmire, 1272.

İbn Hazm, Ali b. Ahmed. el-İhkâm fî usûli'l-ahkâm. 2 Cilt. Beyrut: Dârü'l- Kütübi'l-ìlmiyye, ts.

İbn Kayyım, Şemsüddîn Ebû Abdillah Muhammed b. Ebî Bekr. I'lâmu'l-muvakkî̂n an Rabbi'l-Âlemîn. 4 Cilt. Beyrut: Dâru'l-Cîl, ts.

İbn Manzûr, Ebu'l-Fadl Cemâlüddîn Muhammed b. Mükrim. Lisânül'-Arab, Kahire: Dâru'l-Fikr, 1.Basım, 1990.

İbn Nedîm, Ebu'l-Ferec Muhammed b. Ebî Ya'kûb en-Nedîm. el-Fihrist. Beyrut: Dâru'l-Ma'rife, ts.

İbn Teymiyye vd., İctihad, Taklîd ve Telfik Üzerine Dört Risâle. haz. Hayreddin Karaman. İstanbul: Dergâh Yayınları, 1982.

İzmirli, İsmail Hakkı. İlm-i Hilâf. nşr. Eşref Hudarî. Dersaâdet: y.y., 1330.

Kahraman, Abdullah. İslam Hukukuna Giriş. Ankara: BíLAY, 2. Basım, 2019.

Karaman, Hayreddin. İslam Hukukunda İctihad. Ankara: Emel Matbaac1lk, ts.

Karaman, Hayreddin. İslam Hukuk Tarihi. İstanbul: Nesil Yayınları, 1989.

Karaman, Hayreddin. İslâmın Işığında Günün Meseleleri. 3 Cilt. İstanbul: İz Yayıncılık, 2001.

Karaman, Hayreddin. "Fikıh Mezhepleri". İctihad, Taklîd ve Telfik Üzerine Dört Risâle. İbn Teymiyye vd.13-31. İstanbul: Dergâh Yayınları, 2. Basım,1982. 
Kardâvî, Yusuf. es-Sahve'l-İslâmiyye beyne'l-ihtilâfi'-meşrût ve't-teferruku'l-mezmûm. Kahire: Dâru'ş-Şurûk, 2001.

Kattân, Mennâ‘. Târîhu't-teșrî́i'l-İslâmî. Kahire: Mektebetü Vehbe, 4. Basım, 1989.

Kerhî, Ubeydullah b. el-Hüseyin b. Dellâl. er-Risâle. thk. ve tsh. Mustafa Muhammed Kabbânî. İstanbul: Eda Neşriyat, 1990.

Kılıçer, M. Esad. İslâm Fıkhında Re’y Taraftarları. Ankara: Diyanet İşleri Başkanlığı Yayınları, 2. Basım, 1994.

K1liçer, M. Esad. “Ehl-i Re'y”. Türkiye Diyanet Vakfi İslâm Ansiklopedisi. 10/520-524. İstanbul: TDV Yayınları, 1994.

Koca, Ferhat. "Hilâf (Mukayeseli İslam Hukuku) İlminin Mahiyeti, Doğuşu, Gelişmesi ve Literatürü”. Mukayeseli İslam Hukuk Düşüncesinin Temellendirilmesi. Ankara: Ankara Okulu Yayınları, 2018.

Koca, Ferhat. "Fetvahâne". Türkiye Diyanet Vakfi İslâm Ansiklopedisi. 12/496-500. İstanbul: TDV Yayınları, 1995.

Koçak, Muhsin vd., İslâm Hukuku. İstanbul: Ensar Neşriyat, 2020.

Köse, Saffet. "Hz. Ömer' in Bazı Uygulamaları Bağlamında Ahkâmın Değişmesi Tartışmalarına Bir Bakış". İslam Hukuku Araştırmaları Dergisi 7 (Nisan 2006), 13-50.

Köse, Saffet. İslam Hukukuna Giriş. İstanbul: Hikmetevi Yayınları, 9. Basım, 2016.

Kur'ân-1 Kerîm Meâli. çev. Hayreddin Karaman vd. Ankara: Diyanet İşleri Başkanlığı Yayınları, 7. Basım, 2017.

Mahmud Abdullatîf, Mahmud. el-ìhtilâfâtu'l-fikhiyye lede'l-itticâhâtil-İslâmiyye el-muâssra. Mansûra: Dâru'l-Vefâ, 2. Basım, 2008.

Makdısı, George. "Şâfiînnin Hukukî Teoloji Anlayışı: Usûl-i Fıkhın Kökenleri ve Önemi”. çev. Sami Erdem, Marmara Üniversitesi İlahiyat Fakültesi Dergisi 13-14-15 (1997), 263-294.

Mervezî, Ebû Abdillah Muhammed b. Nasr. İhtilâfu'l-fukahâ. thk. ve tlk. Muhammed Tâhir Hakîm. Riyad: Dâru Advâi's-Selef, 2000.

Müslim, Ebu'l-Hüseyin Müslim b. Haccâc. el-Câmi'u's-sahîh. 3 Cilt. İstanbul: Çağrı Yayınları, 2. Basım, 1992.

Okur, Kaşif Hamdi. “İslam Hukukunun Oluşumu ve Tarihsel Gelişimi”. İslam Hukukuna Giriş. ed. Hacı Yunus Apaydın. 22-61. Eskişehir: Anadolu Üniversitesi, 2019.

Öğüt, Salim. "Ebû Yusuf". Türkiye Diyanet Vakfi İslâm Ansiklopedisi. 10/260-265. İstanbul: TDV Yayınları, 1994.

Özen, Şükrü. "ïlm-i Hilâf Yahut Fukaha Metoduna Göre Cedel Hakkında Klasik Bir Metin: Menșeu'n-Nazar”. Makâlât 2 (1992), 171-198.

Özen, Şükrü. “ìhtilaf”. Türkiye Diyanet Vakfi İslâm Ansiklopedisi. 21/565-568. Ankara: TDV Yayınları, 2004.

Sübkî, Tâcuddîn Abdülvehhâb b. Ali. Tabakâtu'ş-şâfiitiyyeti'l-kübrâ. thk. Mahmut Muhammed etTannâhî ve Abdülfettâh Muhammed. Kâhire: Dâru İhyâi'l- Kütübi'l-Arabî, 1918.

Şahin, Osman. "Sahabe ve Tâbiûn Müçtehitlerinin Yeni Gelişmeler Karşısındaki Tutumlarının Hukuk Metodoloji Açısından Analizi”. Oş Devlet Üniversitesi İlahiyat Fakültesi İlmi Dergisi 910 (2006), 45-74.

Şerefuddîn, Abdülazîm. Târîhu't-teșrîi'l-İslâmî ve ahkâmu'l-mülkiyye ve'ş-şuf a vel-akd. Bingazi: y.y., 1989.

Şevkânî, Muhammed b. Ali. Neylü'l-evtâr şerhu münteka'l-ahbâr min ehâdîs-i Seyyidil'-Ebrâr. 8 Cilt. Kâhire: Dâru'l-Hadîs, ts.

Taberî, Muhammed b. Cerîr. İhtilâfu'l-fukahâ. Beyrut: Dâru'l-Kütübi'l-İlmiyye, ts. 
Tan, Oğuzhan. "Nevazil Fıkhının Ortaya Çıkışı, Mahiyeti ve Genel Özellikleri”. Fıkıh. ed. İbrahim Çalışkan. Ankara: Ankara Üniversitesi Basımevi, 4. Basım, 2009.

Türkî, Abdullah b. Abdülmuhsin. Esbâbu ihtilâfil-fukahâ. Beyrut: Müessesetü'r-Risâle, 3. Basım, $1431 / 2010$.

Üneys, İbrahim vd. el-Mu'cemü'l-Vesît. 2 Cilt. İstanbul: el-Mektebetü'l-İslâmiyye, ts.

Ünsal, Ahmet. "Mukayeseli Fıkıh Çalışmaları". Flkıh. ed. İbrahim Çalışkan. Ankara: Ankara Üniversitesi Basımevi, 4. Basım, 2009.

Yaman, Ahmet-Çalış, Halit. İslâm Hukukuna Giriş. İstanbul: BiLAY, 5. Basım, 2013.

Zerkeşî, Bedruddîn. Hz. Aișe'nin Sahâbeye Yönelttiği Eleștiriler. nşr. Bünyamin Erul. Ankara: Otto, 4. Basım, 2010.

Zeydan, Abdülkerîm. el-Medhal li dirâseti'ş-şerîati'l-ìslâmiyye. Beyrut: Mektebetü'l-Kuds, 1986.

Zühaylî, Vehbe. Usûlül'-fikhi'-İslâmî, Dımaşk: Dâru'l-Fikr, 1986. 